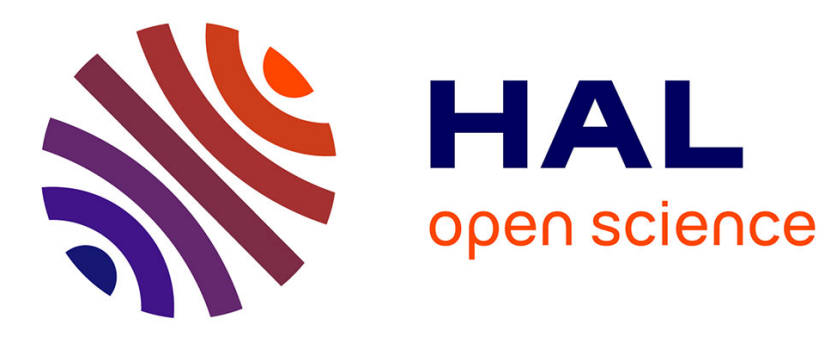

\title{
Development of a flow microsensor for selective detection of nitric oxide in the presence of hydrogen peroxide
}

Raquel Oliveira, Catherine Sella, Christelle Souprayen, Eric Aït-Yahiatène, Cyrine Slim, Sophie Griveau, Laurent Thouin, Fethi Bedioui

\section{To cite this version:}

Raquel Oliveira, Catherine Sella, Christelle Souprayen, Eric Aït-Yahiatène, Cyrine Slim, et al.. Development of a flow microsensor for selective detection of nitric oxide in the presence of hydrogen peroxide. Electrochimica Acta, 2018, 286, pp.365-373. 10.1016/j.electacta.2018.07.158 . hal-02159767

\section{HAL Id: hal-02159767 https://hal.science/hal-02159767}

Submitted on 19 Jun 2019

HAL is a multi-disciplinary open access archive for the deposit and dissemination of scientific research documents, whether they are published or not. The documents may come from teaching and research institutions in France or abroad, or from public or private research centers.
L'archive ouverte pluridisciplinaire HAL, est destinée au dépôt et à la diffusion de documents scientifiques de niveau recherche, publiés ou non, émanant des établissements d'enseignement et de recherche français ou étrangers, des laboratoires publics ou privés. 


\title{
Development of a flow microsensor for selective detection of nitric oxide in the presence of hydrogen peroxide
}

Raquel Oliveira, $^{\mathrm{a}, \mathrm{b}}$, Catherine Sella ${ }^{\mathrm{b}}$, Christelle Souprayen ${ }^{\mathrm{b}}$, Eric Ait-Yahiatene ${ }^{\mathrm{b}}$, Cyrine Slim ${ }^{\mathrm{a}}$, Sophie Griveau ${ }^{\mathrm{a}^{*}}$, Laurent Thouin $^{\mathrm{b}^{*}}$, and Fethi Bedioui ${ }^{\mathrm{a}}$

a Chimie ParisTech, PSL Research University, Unité de Technologies Chimiques et Biologiques pour la Santé, CNRS 8258, INSERM 1022, Univ. Paris Descartes, 75005 Paris, France

${ }^{\mathrm{b}}$ PASTEUR, Département de chimie, École normale supérieure, Université PSL, Sorbonne Université, CNRS, 75005 Paris, France

\begin{abstract}
The detection of reactive oxygen and nitrogen species is of utmost importance in several pathological situations. Indeed, these reactive species are biomarkers of oxidative stress and their real-time monitoring is crucial to adapt medical treatments. We report here on the electrochemical detection of nitric oxide $\left(\mathrm{NO}^{\circ}\right)$ in the presence of hydrogen peroxide $\left(\mathrm{H}_{2} \mathrm{O}_{2}\right)$. The detection was performed by using different sensing microdevices involving either static solutions in wells or flowing solutions in microfluidic channels. Furthermore, an original strategy was proposed to further enhance the selectivity of $\mathrm{NO}^{\bullet}$ detection at $\mathrm{Pt} /$ poly(eugenol) modified platinum electrodes by designing a dual-electrode microfluidic device based on a pre-electrolysis of interfering species including $\mathrm{H}_{2} \mathrm{O}_{2}$ at an upstream electrode prior to $\mathrm{NO}^{\circ}$ detection.
\end{abstract}

\section{Keywords}

Oxidative stress, nitric oxide, poly(eugenol), microchannel, electrochemical sensor 


\section{Introduction}

The study of oxidative stress has become of major importance since it is possible to link the oxidative damage in biomolecules with the manifestation of various diseases such as cancer, blood pressure, Alzheimer, etc [1-2]. The oxidative stress is based on the imbalance between the rate of oxidative damage and the rate at which this damage can be repaired. Its level can be thus determined by the rate of reactive oxygen and nitrogen species (ROS/RNS) that are produced and the rate of their inactivation by antioxidants [3]. Therefore, it is relevant to determine their amount released in biological systems.

Most methods currently available for detecting ROS and RNS are indirect, using chemical or biological labels. It was shown in the literature that some of them are prone to interferences and artifacts. The most commonly developed techniques are chemiluminescence, UV-visible spectroscopy, fluorescence, electron paramagnetic resonance spectroscopy (EPR) and electrochemistry [4-11]. The choice of a technique is dependent upon the desired applications since each technique has individual advantages but also drawbacks that limit their application. These disadvantages arise from lack of sensitivity or specificity to interference from other species commonly present in biological systems. The only strategies that allow direct, realtime, label free and in-vivo detection of ROS and RNS are those based on the use of microelectrodes coupled to electrochemical detection. Indeed, microelectrode design and fabrication are now reaching very high levels of sophistication, hence actively contributing to the promotion of the use of electrochemical techniques by offering the following characteristics: (i) fast response time; (ii) long-term stability; (iii) small size to offer noninvasive and non-destructive close proximity to the site of release; (iv) good selectivity and efficient discrimination against other species; $(v)$ good sensitivity and (vi) ease of handling. Although several ROS and RNS are associated to the oxidative stress, $\mathrm{H}_{2} \mathrm{O}_{2}$ and $\mathrm{NO}^{\circ}$ will be specifically considered in the following. Indeed, their detection can be carried out via 
amperometric measurements at constant potential. However, conventional bare electrodes such as carbon, platinum and gold can be quite easily poisoned in biological medium, often leading to irreproducible results. It is thus necessary to modify the electrode surface to improve the performance and reproducibility of the electrochemical detections. The reality is that surface electrode modification is also needed to make the electrode material selective for the electrochemical oxidation of $\mathrm{NO}^{\circ}$, which occurs at conventional electrode materials at high potentials. Potential values range between 0.7 to $1 \mathrm{~V} v s$ saturated calomel electrode (SCE) in aqueous solutions at $\mathrm{pH}$ 7.4. Such high operating potentials systematically lead to concurrent oxidation of many electroactive species present in solution such as ascorbic acid, dopamine, uric acid, hydrogen peroxide and nitrite. Therefore, the design of modified electrode surfaces using permselective layers is very attractive and provides the ideal strategy to solve the selectivity issues for $\mathrm{NO}^{\circ}$ detection $[5,12-20]$. In the general case, the chemical modification of electrode surfaces with polyelectrolytes and metal complex-based polymer films has expanded the scope of application of such designed electrodes and provided a lot of options for their use in various experimental conditions. An elegant method of electrode modification is the electropolymerization of suitable monomers. Progress in this area was strongly connected to the design of new polymeric systems and to the success in forming thin, insoluble, stable, reproducible and adherent films on electrode surfaces. The major additional advantage of the electropolymerization design is the ability to coat any electrode whatever its shape, geometry or size. In the case where non-conducting polymer films are required, the electropolymerization process also offers the ability to control the film thickness, via the amount of charge passed, by self-regulation, since they would grow thick enough to become insulators. As far as this aspect is concerned, substantial improvements in selectivity, sensitivity, versatility and reproducibility can be achieved. 
In the case of $\mathrm{H}_{2} \mathrm{O}_{2}$, the approach developed to circumvent the limitations due to the use of conventional electrodes is different from that for NO. Pt-black is usually used as a sensing material to enhance the performance of the electrochemical detection of $\mathrm{H}_{2} \mathrm{O}_{2}$. Indeed, the high specific surface area of the deposited Pt-black allows having high number of active sites that contribute to the diminution of the Pt surface passivation $[4,11]$.

Convective flow in microsystems can minimize the inhibition processes of the sensors and increase at the same time the detection sensitivity. Although different electrochemical microsensor arrays were developed to monitor $\mathrm{NO}^{\bullet}$ levels in biological systems (produced by cultured cells or sliced tissues) [8], alone or simultaneously in the presence of other chemical compounds such as nitrite, peroxynitrite or $\mathrm{H}_{2} \mathrm{O}_{2}$ [5-6,21], microfluidic platforms integrating embedded electrodes for the detection of $\mathrm{NO}^{\circ}$ and/or other associated compounds are not numerous $[7,22,23]$. Yet, the control of mass transport in confined space (according to the electrode geometry and space configuration) in association with adequate modifications of electrode surfaces should improve drastically the analytical performance of $\mathrm{NO}^{\bullet}$ detection in the presence of ROS and other RNS [7,23-24].

In this study, we thus investigated a new design of flow microsensor for selective detection of $\mathrm{NO}^{\circ}$ in the low micromolar concentration range, in the presence of $\mathrm{H}_{2} \mathrm{O}_{2}$ and interfering species. The goal was to improve the selectivity of $\mathrm{NO}^{\circ}$ detection by implementing in a microchannel an electrochemical depletion of $\mathrm{H}_{2} \mathrm{O}_{2}$ upstream of the NO sensor. Poly(eugenol) was chosen as a model membrane for the modification of Pt electrode surface since it was reported as one of the best electrogenerated polymeric membranes having excellent performance for the selective amperometric detection of $\mathrm{NO}^{\bullet}[5]$.

Despite the presence of poly(eugenol) as permselective membrane on the electrode surface, $\mathrm{H}_{2} \mathrm{O}_{2}$ can potentially act as an interfering species during $\mathrm{NO}^{\circ}$ detection since it is a small, neutral molecule that oxidizes at lower potentials in comparison to that of NO. It is thus 
important to develop new concepts for $\mathrm{NO}^{\bullet}$ sensing while avoiding the detection of the interfering $\mathrm{H}_{2} \mathrm{O}_{2}$. To reach this aim, a new device will be based on the integration of a second electrode (called hereafter depletion electrode and noted as DE) within the microfluidic channel for the depletion of $\mathrm{H}_{2} \mathrm{O}_{2}$. Fig. 1 shows the concept based on two independent electrodes DE and WE operating simultaneously under constant flow conditions. DE is larger than the WE and is aimed at eliminating upstream the interfering species by inducing their oxidation in flowing solution prior to the detection of the target analyte at WE. DE and WE are biased at potentials such as $E_{\mathrm{DE}}<E_{\mathrm{WE}}$, namely $E_{\mathrm{DE}}=0.45 \mathrm{~V}$ and $E_{\mathrm{WE}}=0.8 \mathrm{~V}$, in order to improve the selectivity. In the present case, DE will be a Pt electrode for the electrochemical depletion of $\mathrm{H}_{2} \mathrm{O}_{2}$ and WE a modified poly(eugenol)/Pt electrode for $\mathrm{NO}^{\bullet}$ detection. The performance of this innovative flow microsensor will be evaluated both theoretically and experimentally and compared to other already established electrochemical microsensors configurations in static and flowing conditions.

\section{Experimental section}

\subsection{Materials and solutions}

Phosphate-buffered saline (PBS) was prepared from tablets (Life Technologies) dissolved into water and composed of $0.01 \mathrm{M}$ phosphate buffer, $0.0027 \mathrm{M}$ potassium chloride and $0.137 \mathrm{M}$ sodium chloride with $\mathrm{pH}$ 7.4. Water was from a Milli-Q purification system (resistivity 18.2 $\mathrm{M} \Omega \mathrm{cm}$ at $25^{\circ} \mathrm{C}$; Millipore).

Hydrogen peroxide was freshly prepared in PBS from stock solutions $\left(\mathrm{H}_{2} \mathrm{O}_{2}: 35\right.$ wt \%, Acros) before experiments. DEA-NONOate (diethylammonium (Z)-1-(N,N-diethylamino)diazen-1ium-1,2-diolate) from Cayman Chemicals was used as NO donor. Stock solutions of DEANONOate $(50 \mathrm{mM})$ were freshly prepared in $0.01 \mathrm{M}$ sodium hydroxide $(\mathrm{NaOH})$ aqueous solution and stored under nitrogen at $-20^{\circ} \mathrm{C}$ to avoid any decomposition. The release of NO 
was initiated by rapidly adding minute volumes of the stock solution to aerated PBS (pH 7.4) at room temperature.

Ascorbic acid (AA, >99\%, Sigma Aldrich), sodium nitrite (99.99\% $\left.\mathrm{NaNO}_{2}\right)$, L-arginine (Arg, $>98 \%$, Sigma Aldrich), glutamine (GLU, >99\%, Sigma Aldrich) and uric acid (UA, >99\%, Sigma Aldrich) were tested as electrochemical interfering species. A $10 \mathrm{mM}$ solution of eugenol was prepared by diluting eugenol (>98\%, Sigma Aldrich) in $0.1 \mathrm{M} \mathrm{NaOH}$ (pellets EMPLURA, Sigma Aldrich) immediately before used. Pt-black deposition solution was prepared from $1 \mathrm{~mL}$ hydrogen hexachloroplatinate (IV) solution (8\% wt in water; SigmaAldrich) and $1.6 \mathrm{mg}$ lead (II) acetate trihydrate (99.8\%; Sigma) added into $6.36 \mathrm{~mL}$ of PBS.

\subsection{Electrodes and electrochemical devices}

Four designs of devices, namely D1, D2, D3 and D4, were considered (Fig. 2). D1 was of a two-electrode cell including a commercial needle-type platinum $(\mathrm{Pt})$ microdisk electrode (Ametek, USA) used as working electrode (WE) and a home-made $\mathrm{Ag} / \mathrm{AgCl}$ electrode wire used both as reference electrode (RE) and counter electrode (CE). D2 consisted of a threeelectrode cell with parallel photolithographed Pt microband electrodes used as WE, CE or pseudo-reference RE on the bottom of the well. Seven microbands could be connected independently to act as WE. As D2, D3 was a three-electrode cell but it was integrated within a microfluidic channel under constant flow conditions. D4 was similar to D3 but consisted of a four-electrode cell with two WEs.

In D2, D3 and D4, Pt microband electrodes (Ti/Pt with $8 \mathrm{~nm} / 25 \mathrm{~nm}$ thickness) were patterned on a glass substrate by soft lithography and deposited using a sputter coater (K675XD; Emitech) [25]. Seven microband electrodes (100 $\mu \mathrm{m}$ wide, 1 to $1.5 \mathrm{~cm}$ long and separated by $900 \mu \mathrm{m}$ gaps) were patterned in D2 and D3 as independent WE. Only one WE was connected during each experiment. CE consisted of three Pt microbands, $200 \mu \mathrm{m}$ wide, separated by 
$40 \mu \mathrm{m}$ gap and short-circuited to a same contact wire. In D4, the design of electrodes consisted of two WEs (2000 and $100 \mu \mathrm{m}$ wide respectively), a pseudo reference RE (200 $\mu \mathrm{m}$ wide) and a CE (2600 $\mu \mathrm{m}$ wide). The gap between the electrodes was 200, 2000 and $1000 \mu \mathrm{m}$ respectively.

The top part in D2, D3 and D4 was made of polydimethylsiloxane, an elastomeric material (PDMS, RTV-615), and pasted to the glass substrate by air plasma. In D2, a well $(0.5 \mathrm{~cm}$ height and $1.5 \mathrm{~cm}$ diameter) was punched to allow $1 \mathrm{~mL}$ solution to be contained. D3 and D4 were similar as those reported in previous works [22-23]. The upper PDMS layer comprised a channel ( $1.5 \mathrm{~cm}$ long, $800 \mu \mathrm{m}$ wide, $24 \mu \mathrm{m}$ height $)$ with reservoirs $(0.3 \mathrm{~cm}$ diameter $)$ molded at both ends of the channel and connected to inlet and outlet tubes across the PDMS matrix. The microbands were positioned transversally to the channel axis. Thus, the effective microband length was delimited by the channel width $(800 \mu \mathrm{m})$. CE was located downstream. In D3 and D4, the flow rate was pressure-driven using a pressure controller (MFCS-FLEX, Fluigent) or a syringe pump (Pump 11 Elite; Harvard Apparatus). A constant average flow rate of $4 \mu \mathrm{L} \mathrm{min}^{-1}$ was controlled by a flow rate platform (FRP, Fluigent). PBS and the electroactive species were introduced in the channel by performing sequential injections of 20 to $35 \mu \mathrm{L}$ using a M-SWITCH system (Fluigent) or via a peek sample loop (Rheodyne) of $20 \mu \mathrm{L}$. These two ways of injection allowed an easy subtraction of the background current monitored initially in PBS.

\subsection{Platinum black and poly(eugenol) electrodeposition}

The deposition conditions of platinum black on $\mathrm{Pt}$ microband working electrodes were precisely described in previous works $[11,22]$. Pt electrodes were modified prior to the bonding of PDMS cover on glass sheet. The reduction of Pt (IV) at Pt microband electrode for Pt-black deposition was performed at a constant current density of $-8 \mathrm{~mA} \mathrm{~cm}^{-2}$ and a charge quantity of $240 \mathrm{mC} \mathrm{cm}^{-2}$. Under these conditions, the thickness of Pt-black deposits was about 
$300 \mathrm{~nm}$, which was fully compatible for applications in micrometric channels. For D3, the electrodeposition was carried out before the PDMS was attached to the glass substrate.

The NO-sensor was prepared by modifying bare Pt working electrode surfaces with a thin layer of poly(eugenol). Electropolymerization was performed at constant potential [26]. The potential was set about $150 \mathrm{mV}$ vs $\mathrm{Ag} / \mathrm{AgCl}$. In each experiment, the value of the potential corresponded to the peak potential monitored initially in eugenol solution by cyclic voltammetry (scan rate $0.1 \mathrm{~V} \mathrm{~s}^{-1}$ ) [5]. The electrode was biased for $15 \mathrm{~min}$ in a solution of $10 \mathrm{mM}$ eugenol and $0.1 \mathrm{M}$ sodium hydroxide. Under these conditions, reproducible and adherent poly(eugenol) films were deposited on the Pt electrode surface. The film thickness was estimated about $50 \mathrm{~nm}$ from AFM measurements (Dimension Edge from Veeco) in tapping mode. For D3 and D4, poly(eugenol) layers were deposited in stagnant flow by using as $\mathrm{CE}$ a Pt wire previously introduced in the output reservoir.

\subsection{Electrochemical experiments}

All electrochemical experiments were performed at room temperature using a Quadstat (eDAQ Pty Ltd, Australia) controlled by Echem software in the case of D1 and a Multipotentiostat (Autolab PGSTAT 30; Eco Chemie) controlled by GPES 4.9 software for D2, D3 and D4. Bare-Pt and Pt/Pt black WEs were previously activated by applying 12 times a potential step from $0 \mathrm{~V}$ (duration $1 \mathrm{~s}$ ) to $-0.5 \mathrm{~V}$ (duration $1 \mathrm{~s}$ ) in PBS solution before each measurement.

Calibration curves for $\mathrm{NO}^{\bullet}$ were established from DEA-NONOate solutions (from 0.1 to $200 \mu \mathrm{M}$ ) so as to obtain $\mathrm{NO}^{\circ}$ concentrations ranging from 0.4 to $6 \mu \mathrm{M}$ (see below). Calibration curves for $\mathrm{H}_{2} \mathrm{O}_{2}$ were established with concentrations ranging from 1 to $200 \mu \mathrm{M}$. For each calibration curve, the limit of detection (LOD) was defined as the equivalent concentration obtained when the signal is three times the standard deviation. The standard 
deviation was calculated by considering the difference of current observed at least between 10 measurements in PBS.

\subsection{UV-Vis measurements and numerical computation}

The differential equation associated to the rate of NO• release from DEA-NONOate and to the rate of $\mathrm{NO}$ consumption via its reaction with $\mathrm{O}_{2}$ was solved numerically using COMSOL Multiphysics 5.3 [23]. A set of DEA-NONOate concentrations was considered with the introduction of rate constants $k_{1}$ and $k_{2}$ values (section 3.1.1). The determination of $k_{1}$ was based on the spectrophotometric study of the DEA-NONOate decomposition which follows a first-order kinetics according to [27]:

$\mathrm{Et}_{2} \mathrm{~N}-\left[\mathrm{N}(\mathrm{O}) \mathrm{NO}^{-} \mathrm{Na}^{+}+\mathrm{H}^{+} \stackrel{\mathrm{k}_{1}}{\rightarrow} 2 \mathrm{NO}+\mathrm{Et}_{2} \mathrm{NH}+\mathrm{Na}^{+}\right.$

$V_{1}=k_{1}\left[\mathrm{Et}_{2} \mathrm{~N}-[\mathrm{N}(\mathrm{O}) \mathrm{NO}]^{-}\right]$

where $V_{1}$ and $k_{1}$ are respectively the rate and the rate constant of the decomposition reaction of DEA-NONOate. Since the efficiency of $\mathrm{NO}^{\circ}$ release in Eq.(1) is about 75\%, 1.5 mole of NO is generated per mole of DEA-NONOate [28]. Secondly, released NO ${ }^{\bullet}$ reacts with dioxygen to produce nitrite according to reaction:

$4 \mathrm{NO}^{-}+\mathrm{O}_{2}+2 \mathrm{H}_{2} \mathrm{O} \stackrel{\mathrm{k}_{2}}{\rightarrow} 4 \mathrm{NO}_{2}^{-}+4 \mathrm{H}^{+}$

which obeys a second order rate law given by:

$V_{2}=4 k_{2}\left[\mathrm{NO}^{\cdot}\right]^{2}\left[\mathrm{O}_{2}\right]$

where $V_{2}$ and $k_{2}$ are the rate and rate constant of the reaction (3) between $\mathrm{NO}$ and $\mathrm{O}_{2}$, respectively. Therefore, the kinetic profile of $\mathrm{NO}^{\bullet}$ release follows the balance between $V_{1}$ and $V_{2}$ 
The value of $k_{2}$ reported in the literature is $(2.1 \pm 0.4) 10^{6} \mathrm{M}^{-2} \mathrm{~s}^{-1}$ at $20-25{ }^{\circ} \mathrm{C}[23,28]$. Since the solubility of dioxygen at $22^{\circ} \mathrm{C}$ is $0.27 \mathrm{mM}$ [29], the value of the product $k_{2}\left[\mathrm{O}_{2}\right]$ was estimated equal to $(550 \pm 100) \mathrm{M}^{-1} \mathrm{~s}^{-1}$.

In order to evaluate $k_{1}$ at different temperatures, the absorbance of DEA-NONOate solutions was monitored using a UV-Vis spectrophotometer (BioTek Instruments Uvikon XL UVVisible) at $\lambda=250 \mathrm{~nm}$. The sample quartz cuvettes were kept at constant temperature $(15,20$, 25 and $30{ }^{\circ} \mathrm{C}$ ) during the measurements using a thermostat (Huber polystat CC2).

The electrochemical depletion implemented in microdevice D4 was evaluated from numerical simulations by using also COMSOL Multiphysics 5.3. The formulation of the problem was identical to that described in previous works [30-32]. The mass transport of the redox species was considered at the microband electrodes under laminar flow. Since the rectangular microchannel was wide, this situation allowed a drastic simplification of the physical problem by permitting its formulation in $2 \mathrm{D}$ space. Assuming that the electrochemical reaction is only limited by mass transport, the diffusion-convection equation was thus solved numerically by finite elements under steady-state regime. Dimensionless parameters were introduced including the concentration $C=c / c_{0}$ of the redox species [30] where $c_{0}$ is the initial concentration. The boundary conditions were imposed by $C=0$ at the electrode surfaces (when connected) and by $C=1$ at the microchannel entrance. No value of electrode potential was thus required for the simulations. In the two operating modes (when one of the two electrodes is On or Off), comparison was established between steady-state currents evaluated as a function of the flow rate by taking into account the geometrical parameters of the microdevice D4 and by introducing the diffusion coefficient of the redox species (namely 1.5 $10^{-5} \mathrm{~cm}^{2} \mathrm{~s}^{-1}$ for $\mathrm{H}_{2} \mathrm{O}_{2}$ ). 


\section{Results and discussion}

\subsection{NO electrochemical sensing conditions}

\subsubsection{Determination of $\mathrm{NO}^{\circ}$ concentration}

Due to its instability, $\mathrm{NO}^{\bullet}$ was obtained from a stock solution of the NO-donor molecule, DEA-NONOate. The $\mathrm{NO}^{\circ}$ concentration results from the competition between the fast decomposition of DEA-NONOate and the slower reaction of $\mathrm{NO}^{\circ}$ with oxygen according to Eqs. 1 and 2. Preliminary studies evidenced that the decomposition rate of diazeniumdiolates depended strongly on its concentration and temperature [28]. Therefore, DEA-NONOate decomposition was investigated from series of UV-Vis spectra performed at different temperatures (section 2.5) using $50 \mu \mathrm{M}$ DEA-NONOate solution in PBS at $\mathrm{pH} 7.4$ to determine the value of $k_{1}$ at the intermediate temperature of $22{ }^{\circ} \mathrm{C}$ at which $k_{2}$ is reported in the literature. The-values of $k_{1}$ then were determined at $\lambda=250 \mathrm{~nm}$ for each temperature leading to $k_{1}\left(15^{\circ} \mathrm{C}\right)=2.6510^{-4} \mathrm{~s}^{-1}, \quad k_{1}\left(20^{\circ} \mathrm{C}\right)=4.3610^{-4} \mathrm{~s}^{-1}, \quad k_{1}\left(25^{\circ} \mathrm{C}\right)=8.0010^{-4} \mathrm{~s}^{-1}$ and $k_{1}\left(30^{\circ} \mathrm{C}\right)=1.2410^{-3} \mathrm{~s}^{-1}$. These values correlated well with those reported in the literature [23,28]. Additionally, the plot of $\ln k_{1} v s(1 / T)$ showed a linear dependency as predicted by Arrhenius law (ln $k_{1}=-91501 / T+23.5, T$ in Kelvin, see Fig. $S 1$ in Supporting information). Various $\mathrm{NO}^{\circ}$ concentration profiles were then calculated as a function of time for a set of initial DEA-NONOate concentrations using the values of $k_{1}$ and $k_{2}\left[\mathrm{O}_{2}\right]\left(\right.$ Fig. 3A) at $T=22^{\circ} \mathrm{C}$. Since $V_{1}$ is much larger than $V_{2}, \mathrm{NO}^{\bullet}$ concentration increases faster at very short times, reaches a maximum after about a hundred of seconds and then decays slowly due to the instability of the radical $\mathrm{NO}^{\circ}$. These profiles were then used to evaluate $\mathrm{NO}^{\circ}$ concentrations under different experimental conditions according to the initial DEA-NONOate concentration and time interval used for current measurement after preparation of DEA-NONOate solution (see below). 


\subsubsection{Electrochemical detection of $\mathrm{NO}^{\circ}$}

The electrochemical oxidation of $\mathrm{NO}^{\bullet}$ occurs currently at high potential values (about 0.7 to $1 \mathrm{~V} v s \mathrm{SCE}$ ). At such potential, many other electroactive species considered as interfering species that can be oxidized and detected, namely nitrite $\left(\mathrm{NO}_{2}^{-}\right)$resulting from $\mathrm{NO}^{-}$reaction with $\mathrm{O}_{2}$. As mentioned in the introduction, the modification of the Pt surface with poly(eugenol) was chosen to increase the electrode selectivity [5]. Poly(eugenol) forms a thin, insoluble, stable, reproducible and adherent film on the Pt electrode surface. This membrane blocks the interfering species due to molecular size exclusion and hydrophobic/hydrophilic features but allows selective detection of $\mathrm{NO}^{\circ}$.

Although under static conditions the diffusion regimes are presumably the same in D1 and D2 devices, the study of their performance by polarizing the Pt/poly(eugenol) electrode at $0.8 \mathrm{~V}$ vs $\mathrm{Ag} / \mathrm{AgCl}$ to detect $\mathrm{NO}^{\circ}$ was achieved in order to make sure that the performance of $\mathrm{D} 2$, which will be further compared to that of D3, is accurate. For D1 or D2 and before each measurement, a known quantity of DEA-NONOate was added after stabilization of the current baseline in PBS. Then, the current was measured in the time interval between 200 and $350 \mathrm{~s}$ after addition of DEA-NONOate alkaline solution. Note that during this time interval, the variation of $\mathrm{NO}^{\circ}$ concentration (and therefore the detection current) was less sensitive to the kinetics of $\mathrm{NO}^{\circ}$ decomposition (see time interval from simulated curves in Fig. 3A). Calibration curves were then established by plotting each current as a function of the estimated concentration of $\mathrm{NO}^{\circ}$. The calibration curve obtained for D2 is reported in Fig. 3B. The sensitivity $\mathrm{S}_{\mathrm{NO}}$ of $\mathrm{NO}^{\bullet}$ detection was deduced from the slope of the calibration curve and LOD was evaluated as described in experimental section. Similarly, NO` detection using D3 and Pt/poly(eugenol) electrodes is illustrated in Fig. 4A. After each injection in the circuit of a DEA-NONOate solution, one current value was recorded within the same time interval 
mentioned previously. The corresponding calibration curve was then established and plotted in Fig. 4B.

For comparison, similar experiments were also achieved on $\mathrm{Pt}$ (for D2 and D3) and $\mathrm{Pt} / \mathrm{Pt}$ black electrodes (for D3). Calibration curves were reported in the supporting information (Fig. S2). All values of $\mathrm{S}_{\mathrm{NO}}$ and LOD deduced from calibration curves were given in Table 1 . Under static conditions (with no forced convection) the diffusion regimes are presumably the same in D1 and D2 devices. Thus Pt/poly(eugenol) electrodes afford similar $\mathrm{S}_{\mathrm{NO}}$ values that are comparable to others given in literature $[26,33]$. However, they are larger than $S_{N O}$ values obtained for bare-Pt for which electrode passivation may be observed. Under dynamic conditions (flow conditions), $\mathrm{S}_{\mathrm{NO}}$ values are much higher than under static conditions due to the enhancement of mass transport at the electrodes. As expected [8], the highest performance was obtained at $\mathrm{Pt} / \mathrm{Pt}$ black electrodes with $\mathrm{S}_{\mathrm{NO}}$ value close to $37 \mathrm{nA} \mu \mathrm{M}^{-1} \mathrm{~mm}^{-2}$ (calculation considering the geometric surface of the initial Pt electrode) and LOD down to $0.05 \mu \mathrm{M}$. Results under dynamic conditions confirm that the presence of the permeating poly(eugenol) membrane promotes $\mathrm{NO}^{\bullet}$ detection as compared to bare Pt. However, $\mathrm{S}_{\mathrm{NO}}$ at Pt/poly(eugenol)

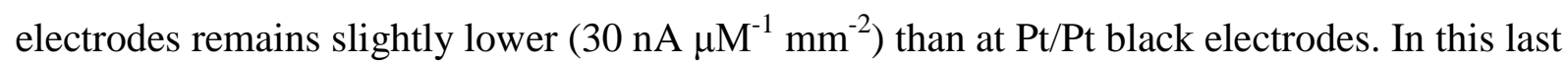
case, the roughness of the Pt-black deposit increases probably the specific surface area leading to higher electrode performance [22-23]. The LOD in D3 at Pt/Pt black electrodes is higher than the one reported in [22-23] since experimental conditions were not similar (geometry of electrode, flow rate and range of NO concentrations investigated). 
Table 1: Sensitivities $\mathrm{S}_{\mathrm{NO}}$ and LOD for NO ${ }^{\bullet}$ detection* with various amperometric sensors** using D1, D2 and D3 devices.

\begin{tabular}{|c|c|c|c|c|}
\hline & Electrode & Device & $\mathrm{S}_{\mathrm{NO}}\left(\mathrm{nA} \mu \mathrm{M}^{-1} \mathrm{~mm}^{-2}\right)$ & $\operatorname{LOD}(\mu \mathrm{M})$ \\
\hline \multirow{4}{*}{ Static } & \multirow[t]{2}{*}{ Bare Pt } & D1 & $2.68 \pm 0.75$ & n.d. \\
\hline & & D2 & $2.61 \pm 0.08$ & 1.66 \\
\hline & \multirow[t]{2}{*}{ Pt/poly(eugenol) } & D1 & $3.94 \pm 0.29$ & 0.93 \\
\hline & & D2 & $3.54 \pm 0.51$ & 0.63 \\
\hline \multirow{3}{*}{ Dynamic } & Bare Pt & \multirow{3}{*}{ D3 } & $8.42 \pm 1.51$ & 2.23 \\
\hline & $\mathrm{Pt} / \mathrm{Pt}$ black & & $37.50 \pm 0.49$ & 0.05 \\
\hline & Pt/poly(eugenol) & & $30.25 \pm 0.99$ & 0.08 \\
\hline
\end{tabular}

$* \mathrm{NO}^{*}$ concentration range: 0.4 to $6 \mu \mathrm{M}$. $* * E=0.8 \mathrm{~V} v s \mathrm{Ag} / \mathrm{AgCl}$.

\subsection{Selectivity of $N O^{\bullet}$ sensor}

$\mathrm{H}_{2} \mathrm{O}_{2}$ oxidation was investigated under the same conditions as previously described for $\mathrm{NO}^{\bullet}$ detection. Indeed, it is relevant at this point to estimate the interferences due to $\mathrm{H}_{2} \mathrm{O}_{2}$ at the $\mathrm{Pt} /$ poly(eugenol) electrodes. Indeed, several studies pointed out the permselectivity of the film towards $\mathrm{H}_{2} \mathrm{O}_{2}$ [34-37]. Electrochemical oxidation of $\mathrm{H}_{2} \mathrm{O}_{2}$ was then investigated at $0.8 \mathrm{~V} v \mathrm{~s}$ $\mathrm{Ag} / \mathrm{AgCl}$, which corresponds to the one required for $\mathrm{NO}^{\bullet}$ detection. For comparison, all data were collected in Table 2. Calibration curves were reported in Fig. S3 of the supporting information.

The results showed that the influence of $\mathrm{H}_{2} \mathrm{O}_{2}$ can be slightly observed at $\mathrm{Pt} / \mathrm{poly}$ (eugenol) electrodes. However, the currents remain very weak in comparison to those measured at bare $\mathrm{Pt}$ and $\mathrm{Pt} / \mathrm{Pt}$ black electrodes. It should be emphasized also that between D2 and D3 convective flow enhanced the permselectivity of the poly(eugenol) membrane against $\mathrm{H}_{2} \mathrm{O}_{2}$. 
Nevertheless, it was possible under these conditions to monitor a steady-state voltammogram in the presence of $\mathrm{H}_{2} \mathrm{O}_{2}$ (Fig. 5A) and thus to establish a calibration curve (Fig. 5B) for D3 with an estimated LOD of $25 \mu \mathrm{M}$. In comparison to $\mathrm{NO}^{\circ}$, this value is 300 times higher but cannot be neglected for analytical purposes. This shows that $\mathrm{H}_{2} \mathrm{O}_{2}$ may interfere in $\mathrm{NO}^{\circ}$ detection at Pt/poly(eugenol) electrodes.

Calibration curves of $\mathrm{NO}^{\circ}$ obtained in the absence and in the presence of $200 \mu \mathrm{M} \mathrm{H}_{2} \mathrm{O}_{2}$ were also established using D3 (Fig. 6). The results showed that the presence of $200 \mu \mathrm{M} \mathrm{H} \mathrm{H}_{2} \mathrm{O}_{2}$ shifted the $\mathrm{NO}^{\circ}$ calibration curve by a constant value of $50 \mathrm{nA} \mathrm{mm} \mathrm{m}^{-2}$. This shift was in good agreement with the current density expected for the separate detection of $200 \mu \mathrm{M} \mathrm{H}_{2} \mathrm{O}_{2}$ (see Fig. 5B). This result demonstrated the additivity between currents within the range of NO concentrations investigated.

Table 2: Sensitivities $\mathrm{S}_{\mathrm{H} 2 \mathrm{O} 2}$ and LOD for $\mathrm{H}_{2} \mathrm{O}_{2} *$ with various amperometric sensors** using D1, D2 and D3 devices.

\begin{tabular}{|c|c|c|c|c|}
\hline & Electrode & Device & $\mathrm{S}_{\mathrm{H} 2 \mathrm{O} 2}\left(\mathrm{nA} \mu \mathrm{M}^{-1} \mathrm{~mm}^{-2}\right)$ & $\mathrm{S}_{\mathrm{H} 2 \mathrm{O} 2} / \mathrm{S}_{\mathrm{NO}}$ \\
\hline \multirow{3}{*}{ Static } & Bare Pt & D2 & n.d. ${ }^{a}$ & n.d. $^{a}$ \\
\hline & \multirow{2}{*}{ Pt/poly(eugenol) } & D1 & $0.83 \pm 0.58$ & $0.21 \pm 0.15$ \\
\hline & & D2 & $0.73 \pm 0.40$ & $0.21 \pm 0.12$ \\
\hline \multirow{3}{*}{ Dynamic } & Bare Pt & \multirow{3}{*}{ D3 } & $20.13 \pm 5.76$ & $2.39 \pm 0.81$ \\
\hline & Pt/Pt-black & & $34.38 \pm 3.18$ & $0.92 \pm 0.09$ \\
\hline & Pt/poly(eugenol) & & $0.24 \pm 0.05$ & $0.008 \pm 0.002$ \\
\hline
\end{tabular}

* $\mathrm{H}_{2} \mathrm{O}_{2}$ concentration range was 1 to $10 \mu \mathrm{M}$, except for D3 with $\mathrm{Pt} /$ poly(eugenol) where concentrations ranged from 12.5 to $200 \mu \mathrm{M}$. **E $=0.8 \mathrm{~V} v s \mathrm{Ag} / \mathrm{AgCl}$. $\mathrm{S}_{\mathrm{NO}}$ values used are those reported in Table 1. ${ }^{a}$.n.d. : Not determined. The results were not reproducible due to the passivation of the Pt electrodes within the timescale of the experiments. 
The selectivity of $\mathrm{NO}^{\circ}$ sensors with respect to a given interfering species potentially present in solution led to the comparison of sensitivities by evaluating the ratio $S_{\text {interferent }} / S_{\mathrm{NO}}$. Due to the complexity of biological systems, it was not possible to study exhaustively the selectivity against many interfering species. Therefore, we choose to focus on species mainly encountered in biological systems and characterized by different charges and sizes. In the following, AA, GLU, Arg, $\mathrm{NO}_{2}{ }^{-}$and UA were selected and experiments were carried out at Pt/poly(eugenol) electrodes using D3. The species were added to PBS concentrations ranging between 0 to $200 \mu \mathrm{M}$. As expected, values for AA, GLU, Arg, $\mathrm{NO}_{2}{ }^{-}$and UA could not be precisely evaluated since no substantial increase of the baseline current was observed after addition. In comparison, only the selectivity towards $\mathrm{H}_{2} \mathrm{O}_{2}$ could be calculated with $\mathrm{S}_{\mathrm{H} 202} / \mathrm{S}_{\mathrm{NO}}$ values around 0.008 (Fig. 7). As demonstrated previously, the poly(eugenol) membrane does not fully block the transport of $\mathrm{H}_{2} \mathrm{O}_{2}$. Nevertheless, these observations confirmed the permselectivity of the electrodeposited membrane towards five main interfering species in a biologically relevant concentration range and validated the conditions used here for electropolymerization of eugenol at Pt microband electrodes.

\subsection{Improvement of the selectivity of $\mathrm{NO}^{\bullet}$ detection in the presence of $\mathrm{H}_{2} \mathrm{O}_{2}$}

\subsubsection{Principle of the new microfluidic device D4}

To improve the selectivity of $\mathrm{NO}^{\bullet}$ detection in the presence of $\mathrm{H}_{2} \mathrm{O}_{2}$ or other interfering species, an original approach was proposed by developing the microfluidic device D4 (Fig. 2) which is composed of two independent electrodes operating simultaneously but independently. The depletion electrode DE, located upstream is used to quantitatively oxidize $\mathrm{H}_{2} \mathrm{O}_{2}$ before the passage of the flowing solution over the second electrode WE (Fig. 1). DE is a large $\mathrm{Pt}$ electrode biased at $0.45 \mathrm{~V}$ for total depletion of $\mathrm{H}_{2} \mathrm{O}_{2}$ while WE is a Pt/poly(eugenol) electrode polarized at $0.8 \mathrm{~V}$ dedicated for $\mathrm{NO}^{\bullet}$ detection. In such a case, 
performance in detection selectivity will depend both on the geometry of the device (i.e., electrode sizes and microchannel dimensions) and flow rate.

\subsubsection{Theoretical performance of device D4}

For optimal performance of the device, two conditions need to be fulfilled. The first one is that DE operates under a thin-layer regime in order to achieve a total depletion (quantitative electrolysis) of $\mathrm{H}_{2} \mathrm{O}_{2}$ upstream [30]. The second one is that WE probes downstream an homogeneous solution after the action of DE [32]. Thus, to ensure a thin-layer regime at DE and to avoid at the same time any interactions between DE and WE, the geometry of D4 was defined on the basis of theoretical criteria previously established [30,32]. The selected geometry is described in experimental section. According to the rectangular section of the microchannel, the performance of the microdevice was then simulated by considering the two-dimensional space described in Fig. 8A. The flow was assumed to be laminar with a parabolic flow profile. DE and WE were supposed to be bare conductive materials without any chemical modification of their surface. Other details about the simulations were reported in experimental section. According to the geometry of the device where the microband electrodes are located on one side of the channel, the quantitative detection of the redox species depends on their confining effect which is mainly controlled by the relative dimensions of the microchannels versus the electrodes. Two situations were envisaged during $\mathrm{NO}^{\bullet}$ detection, i.e., when $\mathrm{DE}$ was disconnected (OFF) or biased (ON). In both cases, the current densities $j^{\mathrm{OFF}}$ and $j^{\mathrm{ON}}$ at $\mathrm{WE}$ were calculated in order to assess the depletion efficiency through the ratio $j^{\text {ON } / j} j^{\text {OFF }}$. The performance of D4 does not depend on the initial concentration of the redox species and was thus simulated as a function of the flow rate (Fig. 8B). Under these conditions high depletion efficiencies are reached at low $j^{\mathrm{ON}} / j^{\mathrm{OFF}}$ values. Data showed that more than $95 \%$ of $\mathrm{H}_{2} \mathrm{O}_{2}\left(\right.$ when $\left.j^{\mathrm{ON}} / j^{\mathrm{OFF}}=0.05\right)$ is oxidized or 
eliminated by $\mathrm{DE}$ at flow rates below $5 \mu \mathrm{L} \mathrm{min}^{-1}$. This arbitrary threshold defines somehow the optimal working conditions of D4 with regard to its geometry. Note that the permselectivity of poly(eugenol) membrane against $\mathrm{H}_{2} \mathrm{O}_{2}$ was not taken into account in these predictions. Thus, flow rates slightly higher than $5 \mu \mathrm{Lmin}^{-1}$ could still be used experimentally to achieve more than $95 \%$ oxidation of $\mathrm{H}_{2} \mathrm{O}_{2}$.

\subsubsection{Proof of concept}

As for our investigations with D3 and in accordance with the theoretical predictions above, a flow rate of $4 \mu \mathrm{L} \mathrm{min}{ }^{-1}$ was set for $\mathrm{D} 4$ to insure the total electrochemical depletion of $\mathrm{H}_{2} \mathrm{O}_{2}$ at WE. Fig. 9A shows the experimental response obtained by D4 using a $200 \mu \mathrm{M} \mathrm{H}_{2} \mathrm{O}_{2}$ solution. In this case, WE was continuously polarized at $0.8 \mathrm{~V}$ while DE was biased only after a time delay. When DE was unbiased, the current at WE reached the average steady-state value that was expected after injection of $200 \mu \mathrm{M} \mathrm{H}_{2} \mathrm{O}_{2}$ (see Fig. 5B for comparison). When DE was biased, the current dropped effectively to the baseline recorded initially in PBS. This behavior was fully in agreement with the performance expected at such a flow rate with this device. This result was also confirmed for various $\mathrm{H}_{2} \mathrm{O}_{2}$ concentrations. Indeed, when DE was biased, the differences in currents monitored at WE before (base line in PBS) and after $\mathrm{H}_{2} \mathrm{O}_{2}$ injection were equal to almost zero within the experimental errors (Fig. 9B). $\mathrm{S}_{\mathrm{H} 2 \mathrm{O} 2}$ sensitivity that could be evaluated under these conditions was $(0.004 \pm 0.010) \mathrm{nA} \mu \mathrm{M}^{-1} \mathrm{~mm}^{-2}$. Currents from Fig. 5B were also reported in Fig. 9B for comparison. From D3 to D4, $\mathrm{S}_{\mathrm{H} 2 \mathrm{O} 2}$ dropped at least by a factor of 60 . In addition, several $\mathrm{H}_{2} \mathrm{O}_{2}$ and $\mathrm{NO}^{\circ}$ mixtures were also investigated. As before, same conditions were used to produce $\mathrm{NO}^{\bullet}$ concentrations from DEA-NONOate. $\mathrm{H}_{2} \mathrm{O}_{2}$ concentration was kept constant and equal to $200 \mu \mathrm{M}$ while final $\mathrm{NO}^{\circ}$ concentrations ranged between 0.97 and $4.46 \mu \mathrm{M}$. Both electrodes DE and WE were polarized and the currents were monitored at WE. Under these conditions, a new calibration curve could be 
established (Fig. 9C). As observed, the amperometric signals related to $\mathrm{NO}^{\bullet}$ lacked the interfering component since they were comparable to those reported in Fig. $4 \mathrm{~B}$ for $\mathrm{NO}^{\circ}$ solutions in absence of $\mathrm{H}_{2} \mathrm{O}_{2}$. In this case, $\mathrm{S}_{\mathrm{NO}}$ sensitivity was estimated to $(26.5 \pm 3.0)$ $\mathrm{nA} \mu \mathrm{M}^{-1} \mathrm{~mm}^{-2}$ which led, within the experimental errors, to a maximum selectivity with $\mathrm{S}_{\mathrm{H} 2 \mathrm{O} 2} / \mathrm{S}_{\mathrm{NO}}=(0.0002 \pm 0.0005)$. All the results in Figs. 9A-C validated the original concept implemented by microdevice D4. This approach opens the way for performing very selective $\mathrm{NO}^{\bullet}$ detections at Pt/poly(eugenol) electrodes even in the presence of large excess of $\mathrm{H}_{2} \mathrm{O}_{2}$. This strategy remains valid for other interfering species that oxidize at potentials lower than $\mathrm{NO}^{\circ}$

\section{Conclusion}

A new concept of microfluidic device including several microband Pt electrodes was proposed to allow the selective amperometric detection of $\mathrm{NO}$ at physiological $\mathrm{pH}$ in the presence of a large excess of the main interfering species $\mathrm{H}_{2} \mathrm{O}_{2}$. The performance of this new device was compared to several sensing systems used either in wells or microfluidic devices. The results showed that higher performance was achieved under flowing conditions due to the enhancement of the mass transport, leading to higher sensitivities and lower LOD. The detection of $\mathrm{NO}^{\circ}$ at $\mathrm{Pt} /$ poly(eugenol) electrodes leads to higher selectivity against various interfering species that oxidize at the same potential. Nevertheless, the results demonstrated that $\mathrm{H}_{2} \mathrm{O}_{2}$ may be still considered as an interfering species during $\mathrm{NO}^{\circ}$ detection at Pt/poly(eugenol) electrodes. Therefore, to improve the selectivity of $\mathrm{NO}^{\bullet}$ detection against $\mathrm{H}_{2} \mathrm{O}_{2}$ while keeping the original sensitivity and LOD of Pt/poly(eugenol) electrodes, an original concept was introduced and validated successfully. The new device was based on the design of a microfluidic device implementing upstream of the $\mathrm{NO}^{\bullet}$ sensor a microelectrode 
for quantitative $\mathrm{H}_{2} \mathrm{O}_{2}$ depletion. Under these conditions, our results showed that the selectivity of the $\mathrm{NO}^{\bullet}$ sensor against $\mathrm{H}_{2} \mathrm{O}_{2}$ was greatly enhanced. These first results demonstrate that this configuration can be used for many other interfering species that oxidize at lower potentials than $\mathrm{NO}^{\circ}$, widening thus the scope of this investigation.

\section{Acknowledgements:}

This work was supported by the Institut Pierre Gilles de Gennes (IPGG, ANR-10-Labx-31). 


\section{References}

[1] R. Kohen, A. Nyska, Toxicol Pathol 30 (2002) 620.

[2] S. Steven, A. Daiber, J. F. Dopheide, T. Munzel, C. Espinola-Klein, Redox Biol 12 (2017) 787.

[3] T. Finkel, N. J. Holbrook, Nature 408 (2000) 239.

[4] C. Amatore, S. Arbault, Y. Chen, C. Crozatier, I. Tapsoba, Lab. Chip. 7 (2007) 233.

[5] D. Quinton, A. Girard, L. T. Thi Kim, V. Raimbault, L. Griscom, F. Razan, S. Griveau, F. Bedioui, Lab. Chip. 11 (2011) 1342.

[6] A. Nassi, L. To Thi Kim, A. Girard, L. Griscom, F. Razan, S. Griveau, L. Thouin, F. Bedioui, Microchimica Acta 179 (2012) 337.

[7] R. A. Hunter, W. L. Storm, P. N. Coneski, M. H. Schoenfisch, Anal. Chem. 85 (2013) 1957.

[8] S. Griveau, F. Bedioui, Anal. Bioanal. Chem. 405 (2013) 3475.

[9] S. F. Peteu, R. Boukherroub, S. Szunerits, Biosens. Bioelectron. 58 (2014) 359.

[10] M. D. Brown, M. H. Schoenfisch, ACS Sensors 1 (2016) 1453.

[11] Y. Li, A. Meunier, R. Fulcrand, C. Sella, C. Amatore, L. Thouin, F. Lemaître, M. Guille-Collignon, Electroanalysis 28 (2016) 1865.

[12] R. W. Murray, Molecular Design of Electrode Surfaces. John Wiley \& Sons: New York, 1992.

[13] K. Shibuki, D. Okada, Nature 349 (1991) 326.

[14] M. A. T. Gilmartin, J. P. Hart, The Analyst 120 (1995) 1029.

[15] M. N. Friedemann, S. W. Robinson, G. A. Gerhardt, Anal. Chem. 68 (1996) 2621.

[16] M. Pontié, F. Bedioui, J. Devynck, Electroanalysis 11 (1999) 845. 
[17] M. Pontié, C. Gobin, T. Pauporté, F. Bédioui, J. Devynck, Anal. Chim. Acta 411 (2000) 175.

[18] E. Bakker, M. Telting-Diaz, Anal. Chem. 74 (2002) 2781.

[19] F. Bedioui, N. Villeneuve, Electroanalysis 15 (2003) 5.

[20] C. Amatore, S. Arbault, M. Guille, F. Lemaitre, Chem. Rev. 108 (2008) 2585.

[21] L. T. O. Thi Kim, V. Escriou, S. Griveau, A. Girard, L. Griscom, F. Razan, F. Bedioui, Electrochim. Acta 140 (2014) 33.

[22] Y. Li, C. Sella, F. Lemaître, M. Guille Collignon, L. Thouin, C. Amatore, Electroanalysis 25 (2013) 895 .

[23] Y. Li, C. Sella, F. Lemaître, M. Guille-Collignon, L. Thouin, C. Amatore, Electrochim. Acta 144 (2014) 111.

[24] R. A. Hunter, B. J. Privett, W. H. Henley, E. R. Breed, Z. Liang, R. Mittal, B. P. Yoseph, J. E. McDunn, E. M. Burd, C. M. Coopersmith, J. M. Ramsey, M. H. Schoenfisch, Anal. Chem. 85 (2013) 6066.

[25] Z. Matharu, J. Enomoto, A. Revzin, Anal. Chem. 85 (2013) 932.

[26] A. Ismail, S. Griveau, F. d'Orlyé, A. Varenne, F. Bedioui, Electroanalysis 27 (2015) 2857.

[27] L. K. Keefer, R. W. Nims, K. M. Davies, D. A. Wink, Methods in Enzymology 268 (1996) 281.

[28] S. Griveau, C. Dumézy, P. Goldner, F. Bedioui, Electrochem. Commun. 9 (2007) 2551.

[29] G. A. Truesdale, A. L. Downing, Nature 173 (1954) 1236.

[30] C. Amatore, N. Da Mota, C. Sella, L. Thouin, Anal. Chem. 79 (2007) 8502.

[31] C. Amatore, N. Da Mota, C. Sella, L. Thouin, Anal. Chem. 80 (2008) 4976.

[32] C. Amatore, N. Da Mota, C. Lemmer, C. Pebay, C. Sella, L. Thouin, Anal. Chem. 80 (2008) 9483. 
[33] F. Bedioui, D. Quinton, S. Griveau, T. Nyokong, Phys Chem Chem Phys 12 (2010) 9976.

[34] L. J. Murphy, Anal. Chem. 70 (1998) 2928.

[35] G. Calia, P. Monti, S. Marceddu, M. A. Dettori, D. Fabbri, S. Jaoua, R. D. O'Neill, P. A. Serra, G. Delogu, Q. Migheli, Analyst 140 (2015) 3607.

[36] A. Ciszewski, G. Milczarek, Electroanalysis 13 (2001) 860.

[37] P. Monti, G. Calia, S. Marceddu, M. A. Dettori, D. Fabbri, S. Jaoua, R. D. O'Neill, Q. Migheli, G. Delogu, P. A. Serra, Talanta 162 (2017) 151. 


\section{Captions of Figures}

Fig. 1. Illustration of the concept of the electrochemical depletion of electroactive interfering species (here $\mathrm{H}_{2} \mathrm{O}_{2}$ ) within a microfluidic channel prior to $\mathrm{NO}^{\bullet}$ detection (here input solution containing $\mathrm{H}_{2} \mathrm{O}_{2}$ and $\mathrm{NO}^{\circ}$ ). Two independent working electrodes operate simultaneously by amperometry. The upstream electrode (DE) is a large electrode that perform the oxidation of the interfering species (here $\mathrm{H}_{2} \mathrm{O}_{2}$ ). The downstream electrode (WE) is the $\mathrm{NO}^{\circ}$ sensor. Potentials of DE and WE are such as $E_{\mathrm{DE}}<E_{\mathrm{WE}}$, namely $\mathrm{E}_{D \mathrm{E}}=0.45 \mathrm{~V}$ and $E_{\mathrm{WE}}=0.8 \mathrm{~V}$.

Fig. 2. Schematic representations of the different devices: Device D1 with a well and a disc needle-type WE; device D2 with a well and a set of independent microband WEs; device D3 with a microfluidic channel and the same set of microband electrodes in D2; device D4 with a microfluidic channel and a set of microband electrodes comprising upstream a large working electrode (DE) to oxidize interfering species and downstream the working electrode WE for NO` detection.

Fig. 3. Detection of $\mathrm{NO}^{\circ}$ at $\mathrm{Pt} /$ poly(eugenol) microband electrode at $E=0.8 \mathrm{~V}$ vs $\mathrm{Ag} / \mathrm{AgCl}$ using D2 in static conditions. A) Calculated $\mathrm{NO}^{\circ}$ concentration profiles with kinetic parameters $k_{1}=6 \quad \times \quad 10^{-4} \mathrm{~s}^{-1}$ and $\mathrm{k}_{2}\left[\mathrm{O}_{2}\right]=550 \mathrm{M}^{-1} \mathrm{~s}^{-1}\left(22{ }^{\circ} \mathrm{C}\right)$, and DEA-NONOate concentrations: (a) 0.1, (b) 0.5, (c) 1, (d) 2, (e) 12.5, (f) 25, (g) 37.5, (h) 50, (i) 98 and (j) 192.3 $\mu \mathrm{M}$. Vertical dashed lines delimiting the time interval used to measure current intensity in experiments. B) Calibration curve of $\mathrm{NO}^{\circ}$ obtained from experimental current densities for several initial concentrations of DEA-NONOate $0.1,0.5,1,2,12.5,25,37.5,50$ and $193 \mu \mathrm{M}$. Linear curve fit with slope equal to $\mathrm{S}_{\mathrm{NO}}=3.54 \mathrm{nA} \mu \mathrm{M}^{-1} \mathrm{~mm}^{-2}$. 
Fig. 4. Detection of $\mathrm{NO}^{\circ}$ at $\mathrm{Pt} /$ poly(eugenol) microband electrode at $E=0.8 \mathrm{~V}$ vs $\mathrm{Ag} / \mathrm{AgCl}$ using D3 at flow rate $4 \mu \mathrm{Lmin}^{-1}$. A) Chronoamperometric response in PBS solution after injection of $2 \mu \mathrm{M}$ DEA-NONOate prepared at $t=0$. B) Calibration curve of NO (each point corresponds to the average of at least 4 measurements) with concentrations of DEA-NONOate $2,2.5,50$ and $100 \mu \mathrm{M}$. Linear curve fit with slope equal to $\mathrm{S}_{\mathrm{NO}}=31 \mathrm{nA} \mu \mathrm{M}^{-1} \mathrm{~mm}^{-2}$.

Fig. 5. Detection of $\mathrm{H}_{2} \mathrm{O}_{2}$ at $\mathrm{Pt} /$ poly(eugenol) microband electrode using D3 at flow rate $4 \mu \mathrm{L} \min ^{-1}$. A) Steady-state voltammogram established from $2 \mathrm{mM} \mathrm{H}_{2} \mathrm{O}_{2}$ solution. B) Calibration curve of $\mathrm{H}_{2} \mathrm{O}_{2}$ at $E=0.8 \mathrm{~V} v s \mathrm{Ag} / \mathrm{AgCl}$ (each point corresponds to the average of at least 4 measurements and the error bars $\left(\leq 0.2 \mathrm{nA} \mathrm{mm}{ }^{2}\right)$ were equal or less than the size of the symbol). Linear curve fit with slope equal to $0.24 \mathrm{nA} \mu \mathrm{M}^{-1} \mathrm{~mm}^{-2}$.

Fig. 6. Calibration curve of $\mathrm{NO}^{\circ}$ at $\mathrm{Pt} /$ poly(eugenol) microband electrodes using $\mathrm{D} 3$ at $4 \mu \mathrm{L} \min ^{-1}$ from mixtures of $\mathrm{H}_{2} \mathrm{O}_{2}$ and DEA-NONOate. $\left[\mathrm{H}_{2} \mathrm{O}_{2}\right]=200 \mu \mathrm{M}$ and [DEANONOate $]_{\mathrm{t}=0}=2,5,25$ and $50 \mu \mathrm{M}$ (open circles, solid line). $E=0.8 \mathrm{~V} v s \mathrm{Ag} / \mathrm{AgCl}$. Comparison with calibration curve of Fig. 4B (solid circles, solid line).

Fig. 7. Selectivity of $\mathrm{Pt} /$ poly(eugenol) $\mathrm{NO}^{\bullet}$ sensor using $\mathrm{D} 3$ under flowing conditions: Comparison between sensitivity ratios $\mathrm{S}_{\text {interferent }} / \mathrm{S}_{\mathrm{NO}}$ evaluated at $E=0.8 \mathrm{~V} v s \mathrm{Ag} / \mathrm{AgCl}$ in the presence of $\mathrm{H}_{2} \mathrm{O}_{2}, \mathrm{AA}, \mathrm{GLU}, \mathrm{Arg}, \mathrm{NO}_{2}{ }^{-}$or UA. $\mathrm{S}_{\text {interferent }}$ evaluated for interfering species concentration ranging between 0 to $200 \mu \mathrm{M}$.

Fig. 8. Theoretical predictions of D4 performance. A) Two-dimensional space considered for simulations with $w_{\mathrm{DE}}$ and $w_{\mathrm{WE}}$ the electrode widths, $g$ the gap distance between DE and WE, and $h$ the channel height. Illustration of the parabolic profile of flow in x-direction. B) 
Simulated ratio of current densities $j^{\mathrm{ON}} / j^{\mathrm{OFF}}$ at WE as a function of flow rate when DE is biased $\left(j^{\text {ON }}\right)$ or disconnected $\left(j^{\text {OFF }}\right)$. Diffusion coefficient $1.510^{-5} \mathrm{~cm}^{2} \mathrm{~s}^{-1}, w_{\mathrm{DE}}=2000 \mu \mathrm{m}$, $w_{\mathrm{WE}}=100 \mu \mathrm{m}, g=200 \mu \mathrm{m}, h=24 \mu \mathrm{m}$.

Fig. 9. Detection of $\mathrm{H}_{2} \mathrm{O}_{2}$ and $\mathrm{NO}^{\circ}$ at $\mathrm{Pt} /$ poly(eugenol) microband electrodes using D4 in flowing conditions. A) Chronoamperometric response of WE at $E=0.8 \mathrm{~V}$ vs $\mathrm{Ag} / \mathrm{AgCl}$ after injection in PBS of $200 \mu \mathrm{M} \mathrm{H}_{2} \mathrm{O}_{2}$. After $t=332 \mathrm{~s}$, DE is electrically connected and biased at $E=0.45 \mathrm{~V}$ vs $\mathrm{Ag} / \mathrm{AgCl}$. B) Experimental currents monitored from $\mathrm{H}_{2} \mathrm{O}_{2}$ solutions when $\mathrm{DE}$ is biased at $E=0.45 \mathrm{~V} v s \mathrm{Ag} / \mathrm{AgCl}$ (solid circles). Comparison with calibration curve of Fig. 5B (open circles) C) Experimental currents monitored from mixtures of $\mathrm{H}_{2} \mathrm{O}_{2}$ and DEANONOate. $\left[\mathrm{H}_{2} \mathrm{O}_{2}\right]=200 \mu \mathrm{M}$ and [DEA-NONOate] $=5,20$ and $50 \mu \mathrm{M}$ (open circles and solid line). Comparison with data of Fig.4B (solid circles). In A-C) the flow rate was $4 \mu \mathrm{L} \mathrm{min}{ }^{-1}$. 


\section{Supporting Information}

Fig. S1. Analysis of UV-Vis peak intensities in $50 \mu \mathrm{M}$ DEA-NONOate solutions at $\mathrm{pH}=7.4$ and $\lambda=250 \mathrm{~nm}$. Representation of $\ln k_{1}\left(k_{1}\right.$ in $\left.\mathrm{s}^{-1}\right)$ versus $(1 / T, T$ in $\mathrm{K})$ for different temperatures: $15,20,25$ and $30^{\circ} \mathrm{C}$. The linear regression gave $\ln k_{1}=-91501 / T+23.5$.

Fig. S2. Calibration curves for $\mathrm{NO}^{\circ}$ detection using microdevices D1, D2 and D3 with various electrodes. Data from table 1.

Fig. S3. Calibration curves for $\mathrm{H}_{2} \mathrm{O}_{2}$ detection using microdevices D1, D2 and D3 with various electrodes. Data from table 2. 


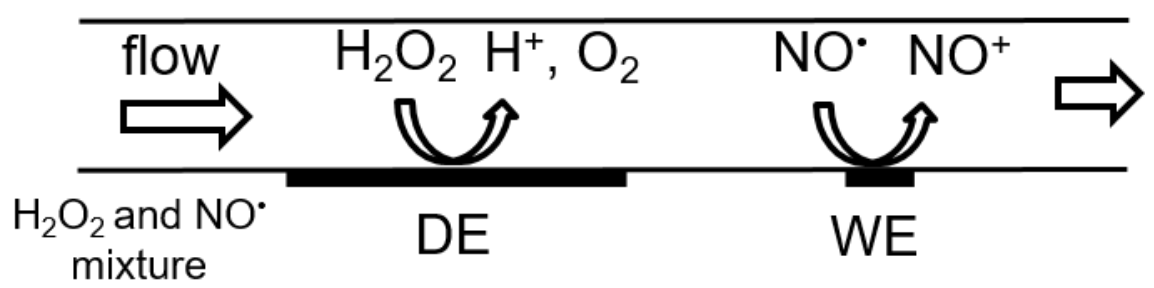

Fig. 1. Illustration of the concept of the electrochemical depletion of electroactive interfering species (here $\mathrm{H}_{2} \mathrm{O}_{2}$ ) within a microfluidic channel prior to $\mathrm{NO}^{\bullet}$ detection (here input solution containing $\mathrm{H}_{2} \mathrm{O}_{2}$ and $\mathrm{NO}^{\circ}$ ). Two independent working electrodes operate simultaneously by amperometry. The upstream electrode (DE) is a large electrode that perform the oxidation of the interfering species (here $\mathrm{H}_{2} \mathrm{O}_{2}$ ). Potentials of DE and WE are such as $E_{\mathrm{DE}}<E_{\mathrm{WE}}$, namely $\mathrm{E}_{D \mathrm{E}}=0.45 \mathrm{~V}$ and $E_{\mathrm{WE}}=0.8 \mathrm{~V}$. 

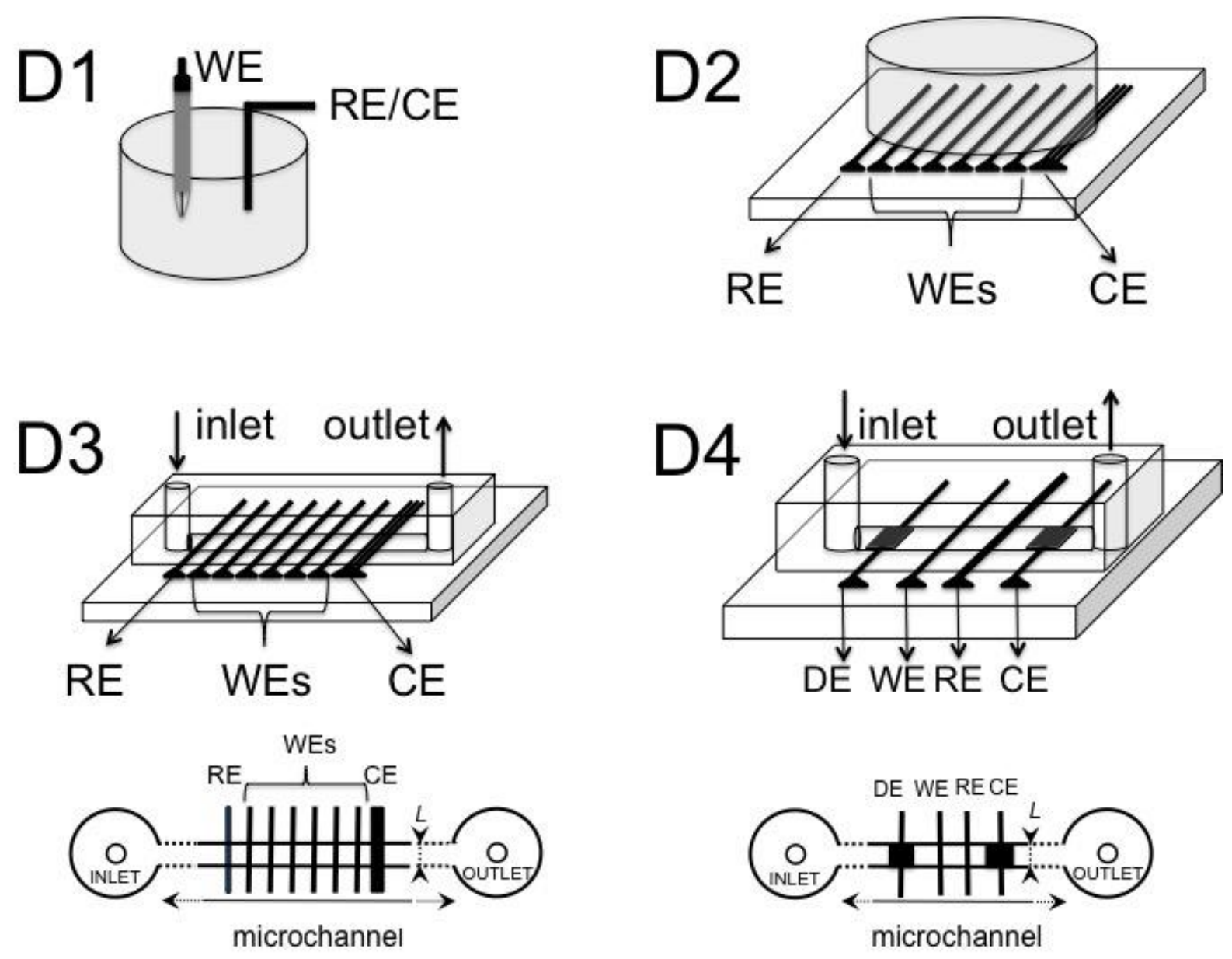

Fig. 2. Schematic representations of the different devices: Device D1 with a well and a disc needle-type WE; device D2 with a well and a set of independent microband WEs; device D3 with a microfluidic channel and the same set of microband electrodes in D2; device D4 with a microfluidic channel and a set of microband electrodes comprising upstream a large working electrode (DE) to oxidize interfering species and downstream the working electrode WE for NO` detection. 

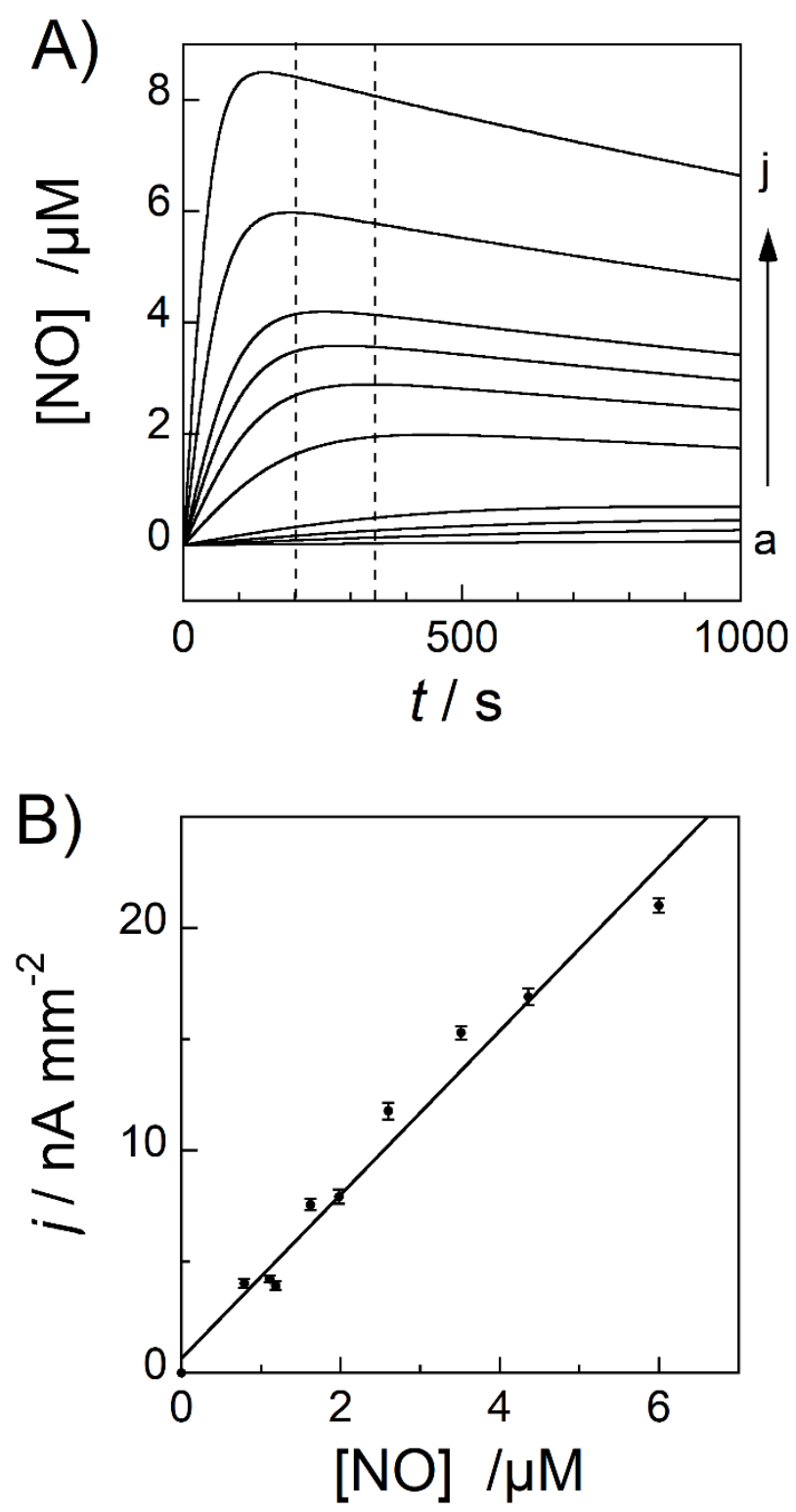

Fig. 3. Detection of $\mathrm{NO}^{\circ}$ at $\mathrm{Pt} /$ poly(eugenol) microband electrode at $E=0.8 \mathrm{~V}$ vs $\mathrm{Ag} / \mathrm{AgCl}$ using D2 in static conditions. A) Calculated $\mathrm{NO}^{\circ}$ concentration profiles with kinetic parameters $k_{1}=6 \quad \times \quad 10^{-4} \mathrm{~s}^{-1}$ and $\mathrm{k}_{2}\left[\mathrm{O}_{2}\right]=550 \mathrm{M}^{-1} \mathrm{~s}^{-1}\left(22{ }^{\circ} \mathrm{C}\right)$, and DEA-NONOate concentrations: (a) 0.1, (b) 0.5, (c) 1, (d) 2, (e) 12.5, (f) 25, (g) 37.5, (h) 50, (i) 98 and (j) 192.3 $\mu \mathrm{M}$. Vertical dashed lines delimiting the time interval used to measure current intensity in experiments. B) Calibration curve of $\mathrm{NO}^{\circ}$ obtained from experimental current densities for several initial concentrations of DEA-NONOate $0.1,0.5,1,2,12.5,25,37.5,50$ and $193 \mu \mathrm{M}$. Linear curve fit with slope equal to $\mathrm{S}_{\mathrm{NO}}=3.54 \mathrm{nA} \mu \mathrm{M}^{-1} \mathrm{~mm}^{-2}$. 

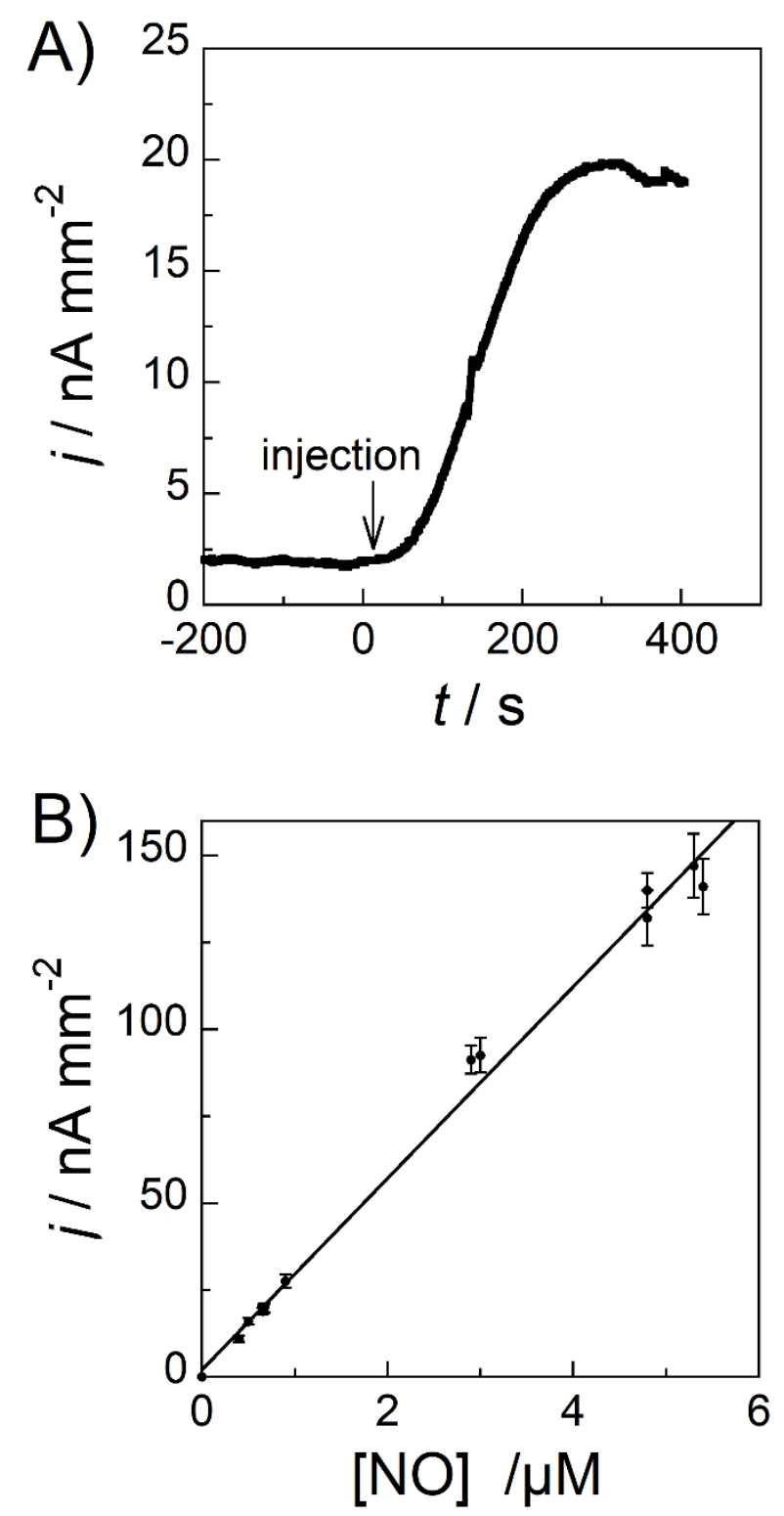

Fig. 4. Detection of $\mathrm{NO}^{\circ}$ at $\mathrm{Pt} /$ poly(eugenol) microband electrode at $E=0.8 \mathrm{~V}$ vs $\mathrm{Ag} / \mathrm{AgCl}$ using D3 at flow rate $4 \mu \mathrm{L} \mathrm{min}{ }^{-1}$. A) Chronoamperometric response in PBS solution after injection of $2 \mu \mathrm{M}$ DEA-NONOate prepared at $t=0$. B) Calibration curve of NO (each point corresponds to the average of at least 4 measurements) with concentrations of DEA-NONOate $2,2.5,50$ and $100 \mu \mathrm{M}$. Linear curve fit with slope equal to $S_{\mathrm{NO}}=31 \mathrm{nA} \mu \mathrm{M}^{-1} \mathrm{~mm}^{-2}$. 

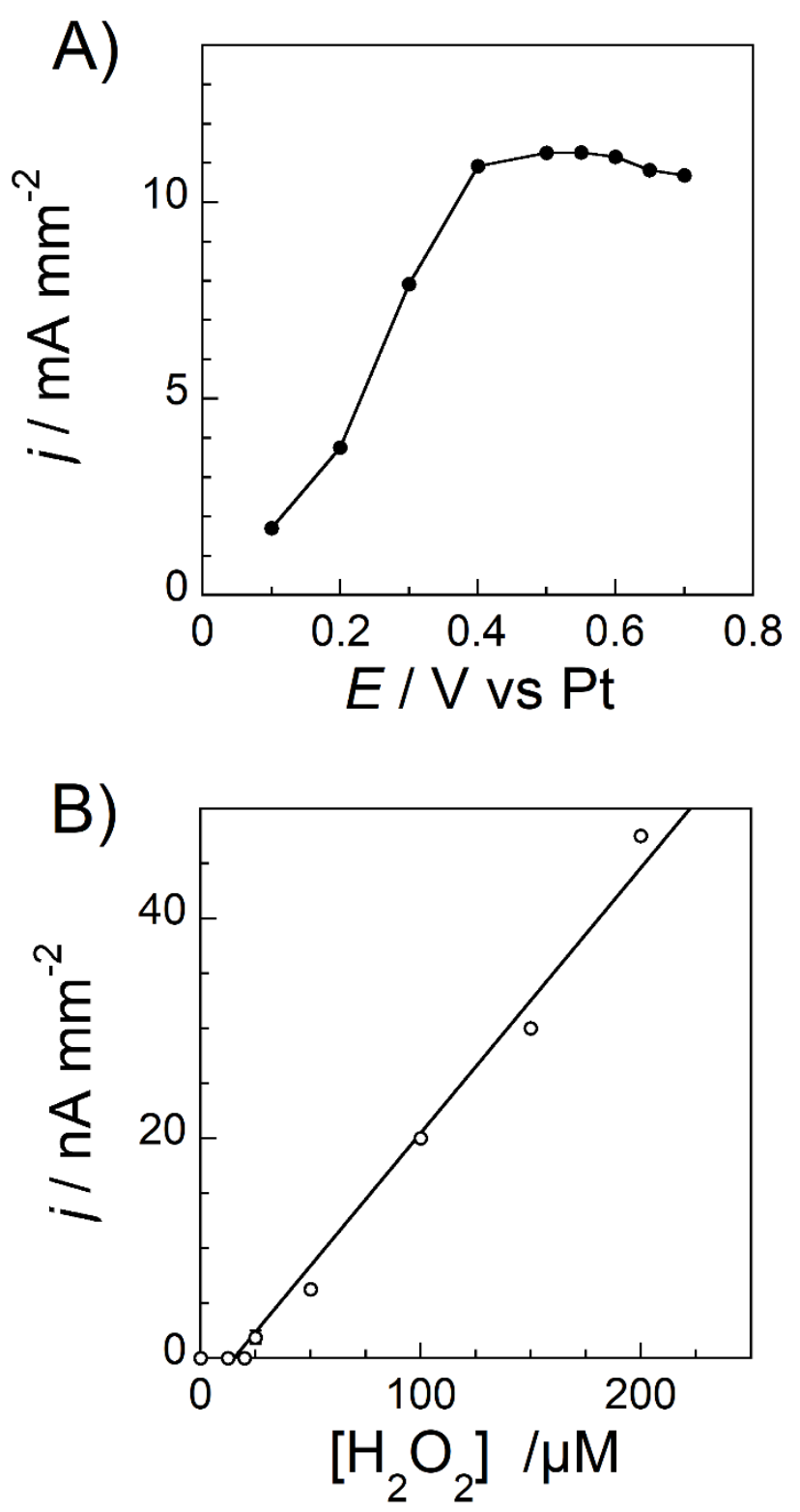

Fig. 5. Detection of $\mathrm{H}_{2} \mathrm{O}_{2}$ at $\mathrm{Pt} /$ poly(eugenol) microband electrode using D3 at flow rate $4 \mu \mathrm{L} \min ^{-1}$. A) Steady-state voltammogram established from $2 \mathrm{mM} \mathrm{H}_{2} \mathrm{O}_{2}$ solution. B) Calibration curve of $\mathrm{H}_{2} \mathrm{O}_{2}$ at $E=0.8 \mathrm{~V}$ vs $\mathrm{Ag} / \mathrm{AgCl}$ (each point corresponds to the average of at least 4 measurements and the error bars $\left(\leq 0.2 \mathrm{nA} \mathrm{mm}{ }^{2}\right)$ were equal or less than the size of the symbol). Linear curve fit with slope equal to $0.24 \mathrm{nA} \mu \mathrm{M}^{-1} \mathrm{~mm}^{-2}$. 


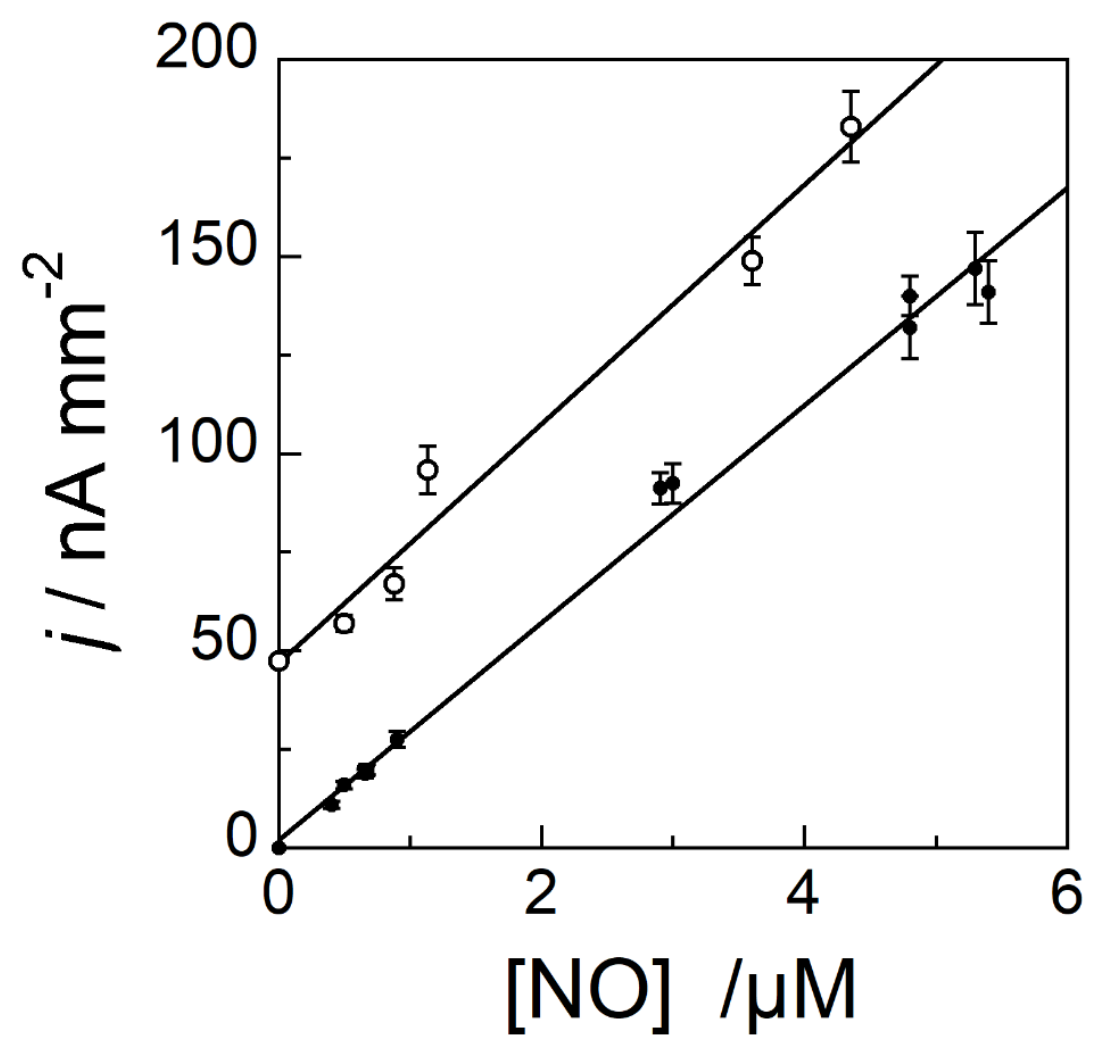

Fig. 6. Calibration curve of $\mathrm{NO}^{\circ}$ at $\mathrm{Pt} /$ poly(eugenol) microband electrodes using $\mathrm{D} 3$ at $4 \mu \mathrm{L} \min ^{-1}$ from mixtures of $\mathrm{H}_{2} \mathrm{O}_{2}$ and DEA-NONOate. $\left[\mathrm{H}_{2} \mathrm{O}_{2}\right]=200 \mu \mathrm{M}$ and [DEANONOate $]_{\mathrm{t}=0}=2,5,25$ and $50 \mu \mathrm{M}$ (open circles, solid line). $E=0.8 \mathrm{~V}$ s $\mathrm{Ag} / \mathrm{AgCl}$. Comparison with calibration curve of Fig. 4B (solid circles, solid line). 


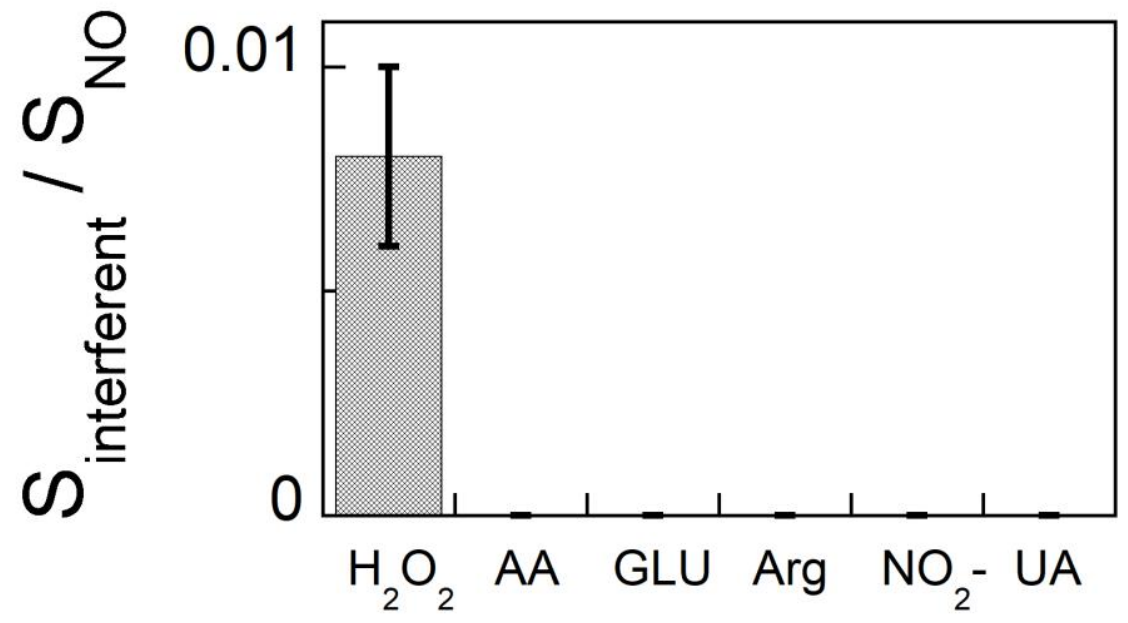

Fig. 7. Selectivity of $\mathrm{Pt} /$ poly(eugenol) $\mathrm{NO}^{*}$ sensor using $\mathrm{D} 3$ under flowing conditions: Comparison between sensitivity ratios $\mathrm{S}_{\text {interferent }} / \mathrm{S}_{\mathrm{NO}}$ evaluated at $E=0.8 \mathrm{~V}$ vs $\mathrm{Ag} / \mathrm{AgCl}$ in the presence of $\mathrm{H}_{2} \mathrm{O}_{2}, \mathrm{AA}, \mathrm{GLU}, \mathrm{Arg}, \mathrm{NO}_{2}{ }^{-}$or UA. $\mathrm{S}_{\text {interferent }}$ evaluated for interfering species concentration ranging between 0 to $200 \mu \mathrm{M}$. 
A)

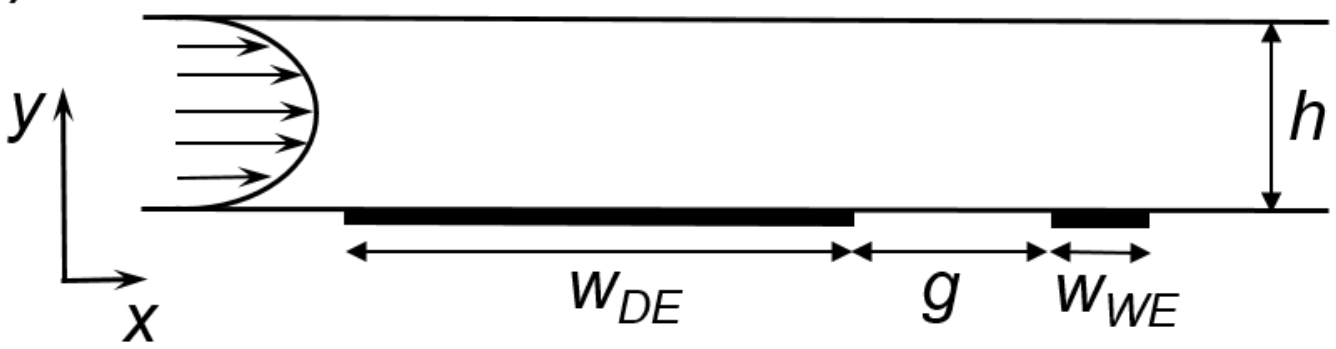

B)

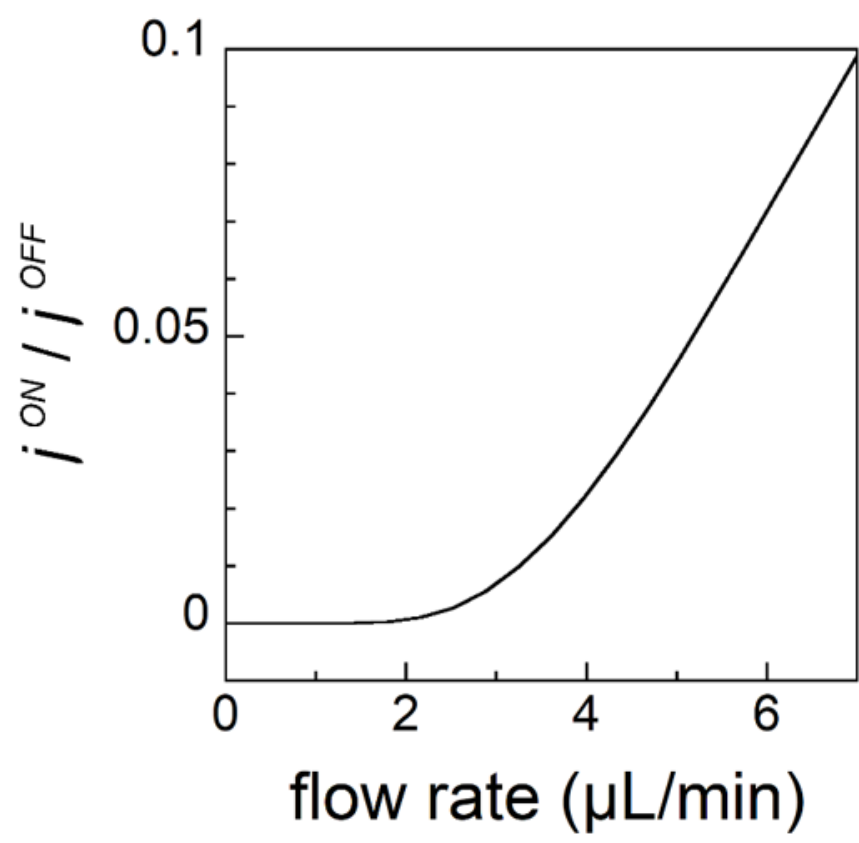

Fig. 8. Theoretical predictions of D4 performance. A) Two-dimensional space considered for simulations with $w_{\mathrm{DE}}$ and $w_{\mathrm{WE}}$ the electrode widths, $g$ the gap distance between DE and WE, and $h$ the channel height. Illustration of the parabolic profile of flow in x-direction. B) Simulated ratio of current densities $j^{\mathrm{ON}} / j^{\mathrm{OFF}}$ at WE as a function of flow rate when DE is biased $\left(j^{\mathrm{ON}}\right)$ or disconnected $\left(j^{\mathrm{OFF}}\right)$. Diffusion coefficient $1.510^{-5} \mathrm{~cm}^{2} \mathrm{~s}^{-1}, w_{\mathrm{DE}}=2000 \mu \mathrm{m}$, $w_{\mathrm{WE}}=100 \mu \mathrm{m}, g=200 \mu \mathrm{m}, h=24 \mu \mathrm{m}$. 

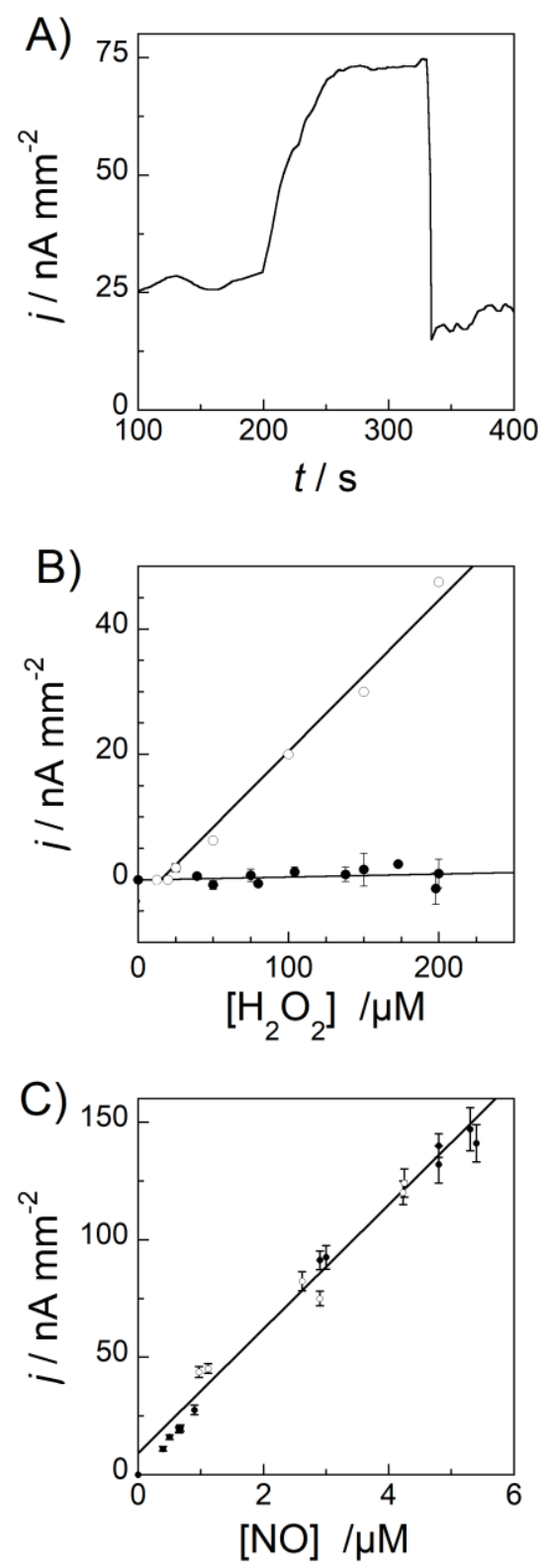

Fig. 9. Detection of $\mathrm{H}_{2} \mathrm{O}_{2}$ and $\mathrm{NO}^{\circ}$ at $\mathrm{Pt} /$ poly(eugenol) microband electrodes using $\mathrm{D} 4$ in flowing conditions. A) Chronoamperometric response of WE at $E=0.8 \mathrm{~V} v s \mathrm{Ag} / \mathrm{AgCl}$ after injection in PBS of $200 \mu \mathrm{M} \mathrm{H}_{2} \mathrm{O}_{2}$. After $t=332 \mathrm{~s}$, DE is electrically connected and biased at $E=0.45 \mathrm{~V} v s \mathrm{Ag} / \mathrm{AgCl}$. B) Experimental currents monitored from $\mathrm{H}_{2} \mathrm{O}_{2}$ solutions when $\mathrm{DE}$ is biased at $E=0.45 \mathrm{~V} v s \mathrm{Ag} / \mathrm{AgCl}$ (solid circles). Comparison with calibration curve of Fig. 5B (open circles) C) Experimental currents monitored from mixtures of $\mathrm{H}_{2} \mathrm{O}_{2}$ and DEANONOate. $\left[\mathrm{H}_{2} \mathrm{O}_{2}\right]=200 \mu \mathrm{M}$ and [DEA-NONOate] $=5,20$ and $50 \mu \mathrm{M}$ (open circles and solid line). Comparison with data of Fig.4B (solid circles). In A-C) the flow rate was $4 \mu \mathrm{L} \mathrm{min}{ }^{-1}$. 


\section{Supporting information}

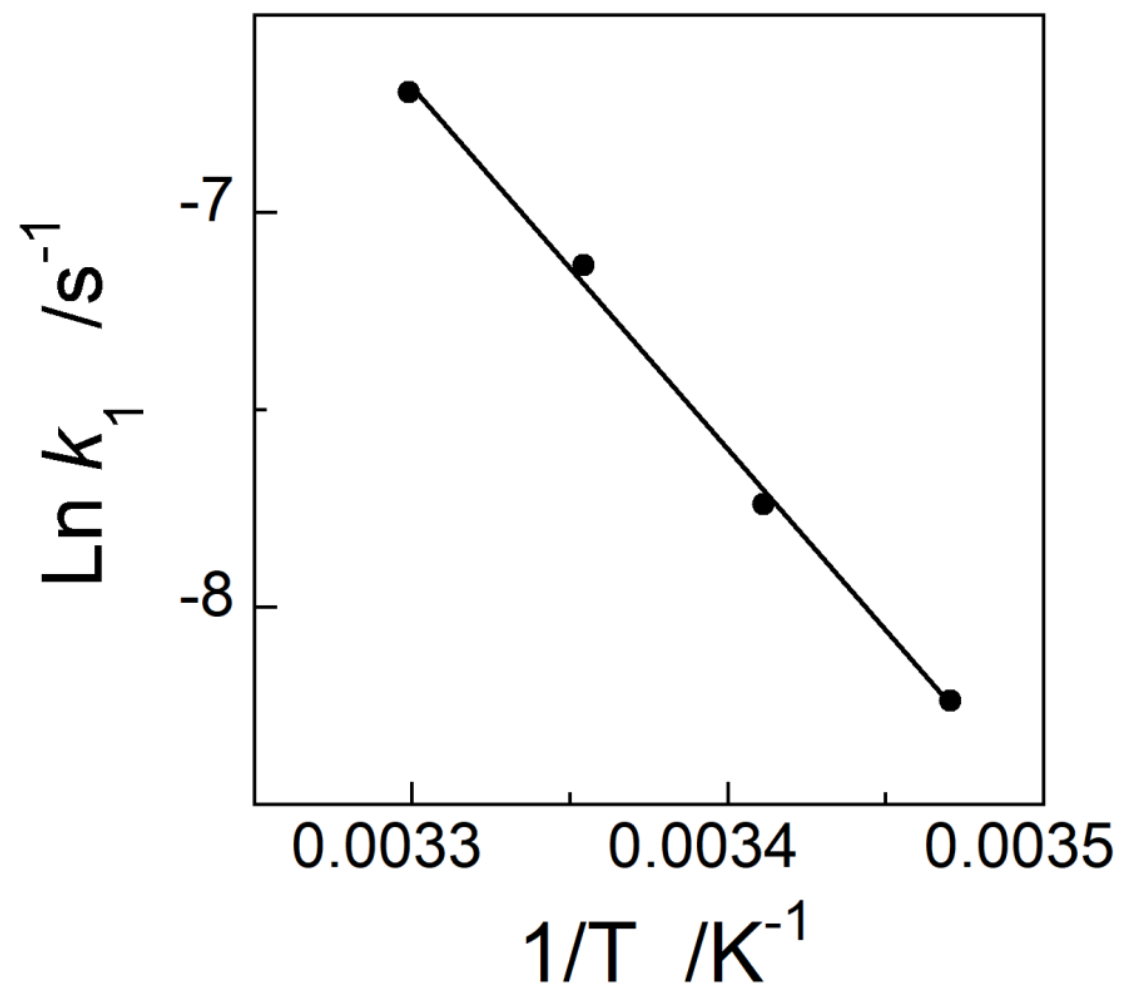

Fig. S1. Analysis of UV-Vis peak intensities in $50 \mu \mathrm{M}$ DEA-NONOate solutions at $\mathrm{pH}=7.4$ and $\lambda=250 \mathrm{~nm}$. Representation of $\ln k_{1}\left(k_{1}\right.$ in $\left.\mathrm{s}^{-1}\right)$ versus $(1 / T, T$ in $\mathrm{K})$ for different temperatures: $15,20,25$ and $30^{\circ} \mathrm{C}$. The linear regression gave $\ln k_{1}=-91501 / T+23.5$. 


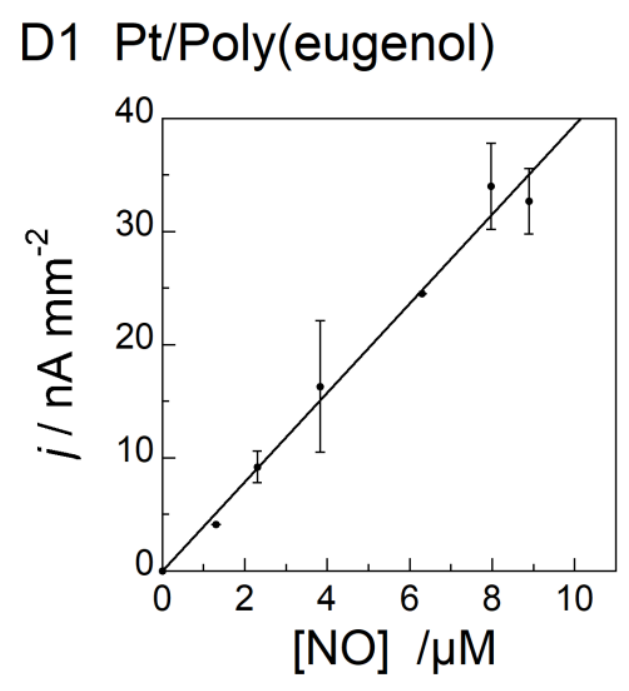

$\mathrm{D} 2$ bare $\mathrm{Pt}$

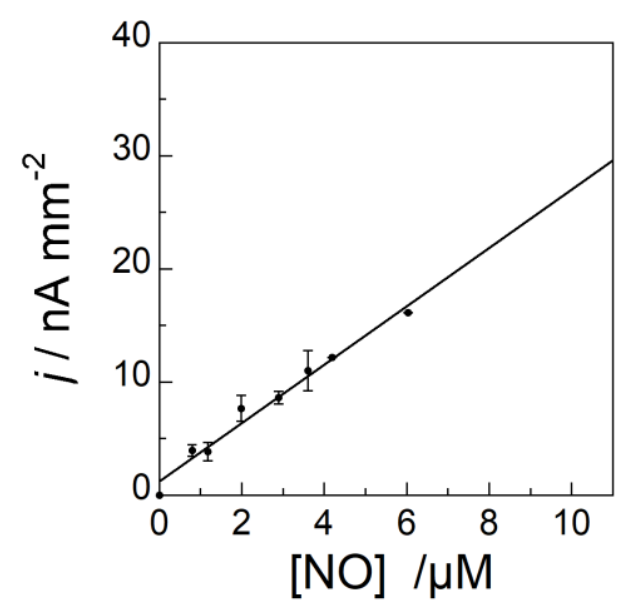

D3 bare Pt and Pt/Pt-black

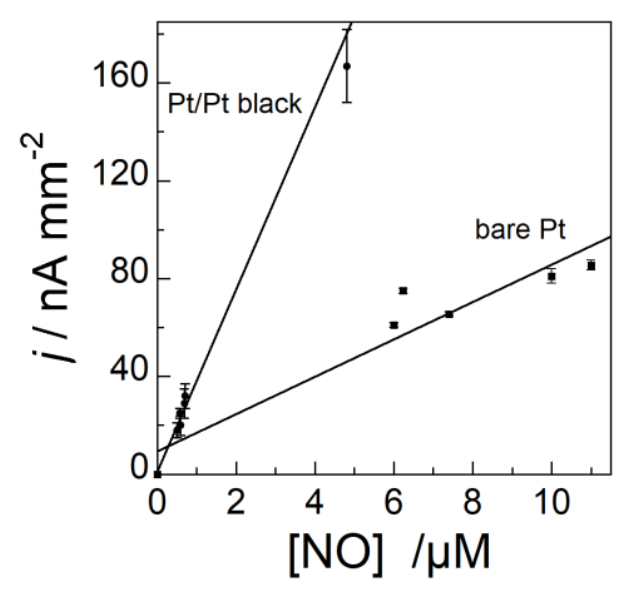

Fig. S2. Calibration curves established for $\mathrm{NO}^{\bullet}$ detection using microdevices D1, D2 and D3 with various electrode modifications. Data from table 1. 

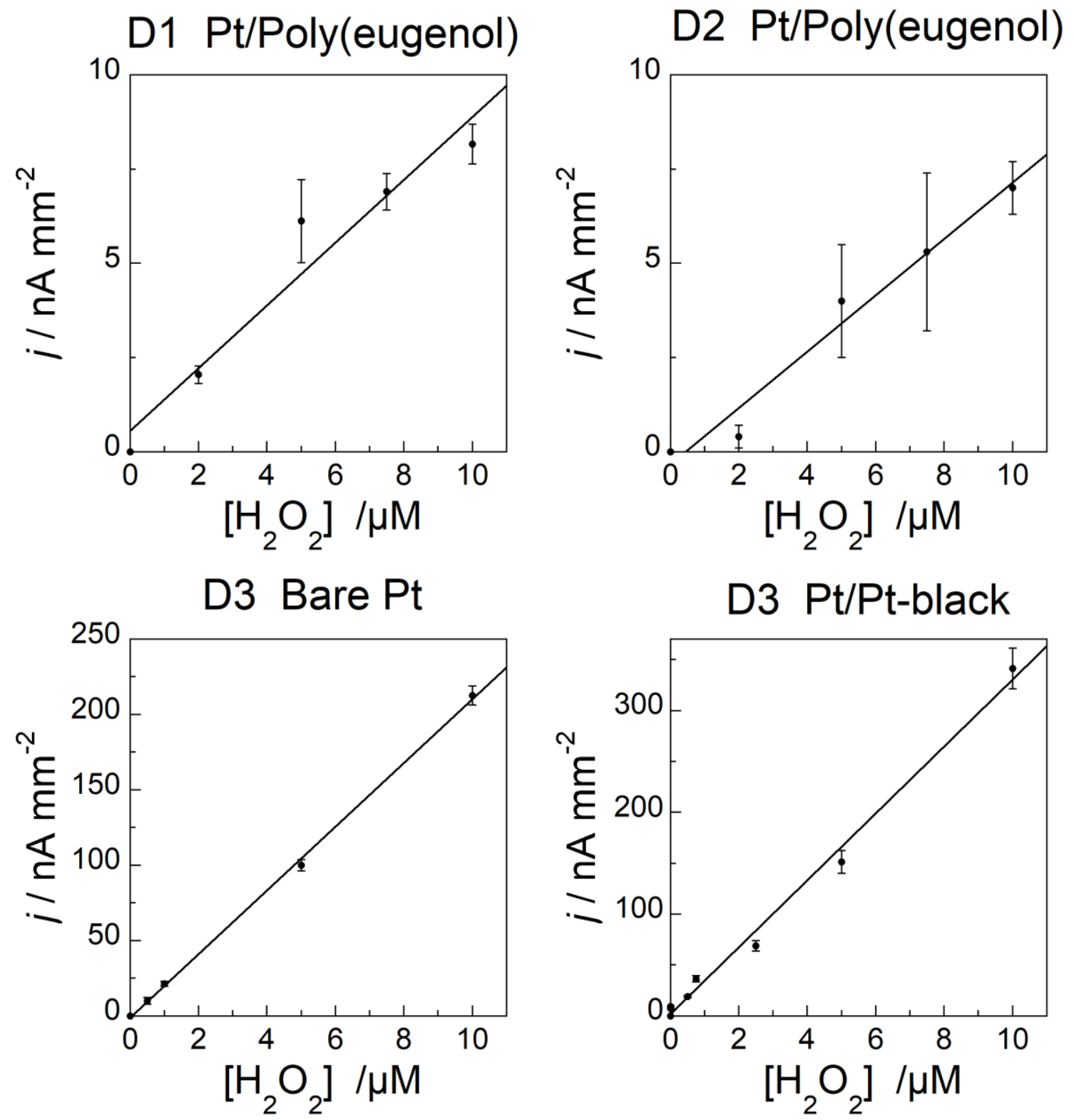

Fig. S3. Calibration curves for $\mathrm{H}_{2} \mathrm{O}_{2}$ detection using microdevices D1, D2 and D3 with various electrode modifications. Data from table 2. 